\title{
EFFECT OF DIETARY SYNTHETIC COENZYME Q10 SUPPLEMENTATION OR NATURAL FROM SOYBEAN OIL ON PRODUCTIVE AND ECONOMICAL PERFORMANCE OF LOCAL LAYING HENS FED LOW ENERGY DIET
}

\author{
M.M. Beshara; Y.S. Rizk; H.M.M. Azouz and H. N. Fahim \\ Anim. Prod. Res. Institute, Agric. Res. Center, Ministry of Agric. Dokki, Giza
}

Received: 24/ 01/2016

Accepted: 15/02/2016

\begin{abstract}
ABSTRAT: A total number of 180 Sinai laying hens at 25 weeks - old were used, weighed and divided into six treatments of three replicates each and housed in individual layer cages to investigate the effect of using two levels of energy ( 2760 or $2660 \mathrm{Kcal} / \mathrm{Kg} \mathrm{diet}$ ) and synthetic (s) or natural source (n) of Coenzyme Q10 (CoQ10) at levels of $(0,7.5 \mathrm{mg} / \mathrm{kg}$ diet CoQ10 (s) or $7.5 \mathrm{mg} / \mathrm{kg}$ diet CoQ10 (n) $)$ in $2 \times 3$ factorial design on the productive performance, profile fatty acids in egg yolk, nutrients digestibility and economical efficiency of local laying hens. Resulted obtained could be summarized in the following:

1- Egg weight of hens fed diet contained low ME significantly increased $(\mathrm{P} \leq 0.05)$ as compared to control diet. While, no significant influence $(\mathrm{P} \geq 0.05)$ of dietary CoQ10 and interaction between CoQ10 and ME on egg weight.

2- Egg production $\%$ and egg mass for hens with low ME was significantly $(\mathrm{P} \leq 0.05)$ higher than hens fed diet with the control diet.

3- Hens fed $7.5 \mathrm{mg}$ CoQ10 $(\mathrm{s})$ had significantly higher $(\mathrm{P} \leq 0.05)$ egg mass by about $5.76 \%$ than CoQ10 (o) (control diet). The best egg mass was recorded by the interaction between $2660 \mathrm{Kcal} / \mathrm{Kg}$ and $7.5 \mathrm{mg}$ CoQ10(s).

4- Feed intake was increased by about $7.49 \%$ for hens fed the low level of ME $(2760 \mathrm{Kcal} / \mathrm{Kg})$ as compared the control diet. While, the diet with CoQ10 (s) was the highest amount of feed intake comparing with CoQ10 (n).

5- Feed conversion was improved by $6.20 \%$ for hens fed diets with $2660 \mathrm{Kcal} / \mathrm{Kg}$ compared to $2760 \mathrm{Kcal} / \mathrm{Kg}$. But, no significant influence of dietary CoQ10 and interaction between CoQ10 and ME on feed conversion ratio.

6- The dietary supplemented with CoQ10(s) and the interaction between dietary $\mathrm{CoQ}_{10}$ or $(\mathrm{n})+$ the low level of ME resulted in a significant increase $(\mathrm{P} \leq 0.05)$ in shell thickness compared to the control diet.

7- The diet contained low level of ME caused a significant decrease $(\mathrm{P} \leq 0.05)$ in heterophil $(\mathrm{H}) \%$ and heterophil / lymphocyte $(\mathrm{L})$ compared to the control diet.

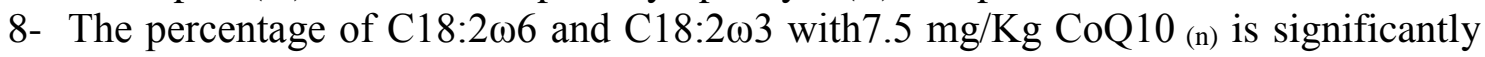
higher $(\mathrm{P} \leq 0.05)$ than those of the control diet. On the other hand the percentages of $\mathrm{C} 20: 4 \omega 6$ was significantly reduced $(\mathrm{P} \leq 0.05)$ in response to the diet contained with7.5 mg/Kg CoQ10(s) comparing with the control and CoQ10 (n).
\end{abstract}

Key Words: Laying hens, Coenzyme Q10, Soybean Oil, Performance, Fatty Acids.

Corresponding author: malakman88@ yahoo.com 
The interaction between 2760 or $2660 \mathrm{Kcal} / \mathrm{Kg}$ diet and $7.5 \mathrm{mg} / \mathrm{Kg} \mathrm{CoQ} 10_{(\mathrm{n})}$ recorded the best percentage of $\mathrm{C} 18: 2 \omega 6$ and $\mathrm{C} 18: 2 \omega 3$ as compared to control and other groups. While, the diet contained ME $2760 \mathrm{Kcal} / \mathrm{Kg}$ diet $+7.5 \mathrm{mg} / \mathrm{Kg} \mathrm{CoQ} 10_{(\mathrm{s})}$ recorded significantly the lowest $(\mathrm{P} \leq 0.05)$ value of $\mathrm{C} 20: 4 \omega 6$ compared to the control diet.

9- Generally SFA (C14:0, C16:0 and C18:0) were decreased in response to the low dietary ME, Co Q10 and by the interaction between ME and CoQ10 compare to the control diet.

10- The percentage of $\mathrm{C} 18: 1 \omega 9, \mathrm{C} 16: 1 \omega 9$ and $\mathrm{C} 18: 1 \omega 7$ of yolks from diet supplemented with $7.5 \mathrm{mg} \mathrm{CoQ} 10_{(\mathrm{s})} / \mathrm{Kg}$ diet were significantly higher $(\mathrm{P} \leq 0.05)$ than the control diet. The interaction between low ME and $7.5 \mathrm{mg}$ CoQ10 (n) had the highest value of $\mathrm{C} 18: 1 \omega 9$ by about $13.15 \%$ comparing with the control. Layers fed diet contained low ME, $7.5 \mathrm{mg}$ CoQ10 (n), and interaction between low ME and7.5mg CoQ10 ${ }_{(\mathrm{s})}$ or $7.5 \mathrm{mg}$ CoQ10 (n) had significantly lower in SFA/UPFA ratio than control.

11- The best $(\mathrm{P} \leq 0.05)$ value of $\mathrm{EE}$ for egg production was produced by interaction between the low level of $\mathrm{ME}+7.5 \mathrm{mg} \mathrm{CoQ10}$ (s) $/ \mathrm{kg}$ diet followed by the diet contained the requirement of ME+ $7.5 \mathrm{mg} \mathrm{CoQ} 10(\mathrm{~s}) / \mathrm{kg}$ diet.

It could be concluded that supplementation $7.5 \mathrm{mg}$ CoQ10 (s) / $\mathrm{kg}$ diet contained low level of ME $(2660 \mathrm{Kcal} / \mathrm{Kg} /$ diet $)$ could be used a functional feed additive in Sinai laying hens during the period from 25 to 40 weeks of age to maximize the productive performance, economic efficiency and improve the internal egg quality in respect of the profile fatty acids.

\section{INTRODUCTION}

Coenzyme Q10 (CoQ10) is natural lipophilic compounds present in each and every living cell; due to its ubiquitous occurrence in nature they are also called Ubiquinone (Haas et al., 2007). Coenzyme Q10 is 2, 3-dimethoxy, 5-methyl, 6polyisoprene Para benzoquinone. Coenzyme Q10 is distributed in all membranes throughout the cell (Kalen et al., 1987). Coenzyme Q10 is chiefly found in the most active organs like the heart, kidney, and liver, where an even greater decline can be observed with increasing age (Kalen et al., 1989). But, relatively high concentrations of CoQ10 are found in the mitochondria of cells where it has a critical role in energy production (Ernster et al., 1995). In the following years the fundamental role of CoQ10 in the mitochondrial respiratory chain and in oxidative phosphorylation was determined and Peter D. Mitchell was awarded the Nobel Prize in Chemistry in 1978 for his contribution to the understanding of the role of CoQ10 for biological energy transfers at the cellular level (Crane, 2007). Coenzyme Q10 is an essential part of the cellular machinery used to produce ATP which provides the energy for muscle contraction and other vital cellular functions. The major part of ATP production occurs in the inner membrane of mitochondria, where coenzyme $\mathrm{Q}$ is found. The coenzyme $\mathrm{Q}$ has a unique function since it transfers electrons from the primary substrates to the oxidase system at the same time that it transfers protons to the outside of the mitochondrial membrane. This transfer results in a proton gradient across the membrane. As the protons return to the interior through the enzymatic machinery for making ATP, they drive the formation of ATP. The coenzyme Q10 is bound to the oriented enzymatic protein complexes. It is oxidized and releases protons to the outside and picks up electrons and protons on the inside of the mitochondrial membrane (Brandt 1999 and Yu et al., 1999). Thus, CoQ10 is well defined as a crucial 
component of the oxidative phosphorylation process in mitochondria which converts the energy in carbohydrates and fatty acids into ATP to drive cellular machinery and synthesis (Crane 2001).

Coenzyme Q10 is also known as a very effective antioxidant (Bentinger et al., 2007), protecting against lipid peroxidation, DNA, and protein oxidation and capable of functioning synergistically with other antioxidants (Challem, 2005).

Scientific publications illustrated that the poultry is quite convenient for fortification with CoQ10 where, Geng et al., (2004) showed that the effective dose of CoQ10 may be as low as $20 \mathrm{mg} / \mathrm{kg}$ in poultry, also found that CoQ10 protects the cell membrane and cell structure against peroxidation and thus more tolerant to the metabolic stress. Two major functions are attributed to CoQ10: it acts as an electron carrier in the mitochondrial respiratory chain and as a lipid-soluble antioxidant (Bhagavan and Chopra 2006). Honda et al. (2013) reported that CoQ10 transferred into the egg yolk, thus it might be used to a functional feed additive in dietary of laying hens. Kikusato et al. (2015) indicates that dietary CoQ10 attenuates the muscular oxidative damage, suggesting that this may be due to the suppression of mitochondrial reactive oxygen species (ROS) production. The production of eggs which are of good egg shell quality and good internal quality is critical to the economic viability of the industry, in chickens, only a few studies have been performed in laying hens for example, scientific publication stated that CoQ10 did not affect egg production rate, the weights of egg and egg yolk, and feed efficiency, but significantly increased CoQ10 content in the egg yolk thus CoQ10 can be promising candidates for feed additives to improve the egg quality (Hasegawa et al., 2009). The findings by Kamisoyama et al. (2010) suggest that, in CoQ10 -fed laying hens, dietary CoQ10 did not affect average egg production rate, feed efficiency, egg weight, and egg yolk weight but Co Q10 content in the egg yolk was increased significantly In study by Tercic et al. (2011) showed that dietary CoQ10 supplementation had no effects on egg weight, albumen height and Haugh units. Beside endogenous synthesis, CoQ10 is also supplied to the organism by various foods.

The results of CoQ10 contents by Italian studies on soybean oil illustrated that the CoQ10 concentration was 221-279 mg / Kg soybean oil (Cabrini et al., 2001 and Pregnolato et al., 1994). The effects of dietary CoQ10 on laying hens fed diet with low ME content have not yet been examined. Thus the current study was conducted to investigate the effect of dietary CQ10 as a functional feed additive in layer diet with low ME on the laying and economical performance as well as on the profile fatty acids in egg yolk.

\section{MATERIALS AND METHODS}

\section{Bird's management and diets:}

This study was conducted at El-Serw Poultry Research Station, Animal Poultry Research Institute, Agriculture Research Center, Ministry of Agriculture, Egypt. One hundred and eighty Sinai laying hens 25 weeks of age were randomly assigned to fed six dietary treatments in an experiment that was conducted from 25 to 40 wks of age. At the onset of the experiment, hens were weighed and assigned to $2 \times 3$ completely randomized design based on two levels of energy (2760 or 2660 $\mathrm{Kcal} / \mathrm{Kg}$ diet) and synthetic source (s) of Coenzyme Q10 (CoQ10) or natural (n) at levels of $\left(0,7.5 \mathrm{CoQ} 10_{(\mathrm{s})}\right.$ or $7.5 \mathrm{CoQ} 10$ (n) Three replicates of 10 hens replicate were fed one the six dietary treatments. Each replicate comprised ten adjacent cages with one hen /cage $(60 \mathrm{~cm}$ long $\mathrm{x} 50 \mathrm{~cm}$ wide $\mathrm{x}$ $60 \mathrm{~cm}$ high). Birds were provided with programmed lighting (16L: 8D). The experimental diets were as the following:The control dietary contained $2760 \mathrm{Kcal}$ $/ \mathrm{Kg}$ diet, The control with $7.5 \mathrm{mg}$ COQ10 synthetic $(7.5 \mathrm{mg}$ CoQ10(s) , the control 
with $7.5 \mathrm{mg}$ CoQ10 from soybean oil at $3.0 \%$ (7.5 mg CoQ10 $(\mathrm{n})$ ), the dietary low level of ME $(2660 \mathrm{Kcal} / \mathrm{Kg}$ diet $)$, the dietary low ME with $7.5 \mathrm{mg}$ COQ10 synthetic $(7.5 \mathrm{mg}$ CoQ10 $(\mathrm{s})$ ), and the dietary low level ME with $7.5 \mathrm{mg}$ CoQ10 from soybean oil at $3.0 \% \quad(7.5 \mathrm{mg}$ CoQ10(n)). The birds were fed a layer diet of soybean meal and yellow corn according to Hussein et al., (2010) recommend. Composition and calculated nutrients of experimental diets presented in Table 1.

\section{Laying performance traits:}

Body weights of hens were recorded during the experiment period $(25-40 \mathrm{wks}$ of age). Egg number and mass and feed consumption were recorded then were averaged and expressed per hen / four wks through the four periods and the overall experimental period (25-40 wks of age). Laying rate and feed conversion ratio were calculated through the same periods as well as change body weight was calculated through the whole experimental period.

Egg quality and profile fatty acid:

At $33^{\text {rd }}$ and $40^{\text {th }} \mathrm{Wk}$ of age of the experiment, the eggs (6 from each treatment) were randomly taken to determine some egg quality parameters such as shape index, yolk index, yolk, albumen and shell weights as a percentage of egg weight, shell thickness and Haugh units. Quantification of FA was done after preparation of FA methyl esters and subsequent fatty acids profiles were obtained by gas-liquid chromatography and reported as percentages.

\section{Nutrients digestibility:}

At the end of experiment, 18 Sinai cocks (three each treatment) were taken to evaluate the digestibility of nutrients for all experimental diets. Cocks were fed their experimental diets for seven days as a preliminary period, followed by three days collection period, where excreta were quantitatively collected. Simultaneously, records of daily feed consumption for each cock were maintained. The daily excreta was voided from males in each treatment, pooled and thoroughly mixed. Then, representative excreta samples were taken and dried immediately in a forced oven at $65 \mathrm{C}^{\mathrm{O}}$ for 48 hours for chemical analysis (AOAC, 1995). The procedure described by Jakobsen et al. (1960) was used for separating fecal protein from excreta samples. Urinary organic matter was determined according to Abou-Raya and Galal (1971). Digestion coefficients were calculated according to the following equation: Digestion coefficient $\%=$ [(Nutrient intake (g) - Fecal nutrient content $(\mathrm{g}))$ / Nutrient intake $(\mathrm{g})] \times 100$.

\section{Hematological parameters:}

Blood samples were collected randomly in vial tubes containing EDTA as anticoagulant. Differential white blood cells (WBC) counts were performed by using standard avian guidelines introduced by Ritchie et al. (1994). Total white blood cells were determined by the Unopett method (Campbell, 1995). Heterophils (H) and lymphocytes (L) were counted in different microscopic fields in a total of $200 \mathrm{WBC}$ by the same person, and the H: L ratios were calculated (Gross and Siegel, 1986).

\section{Economical efficiency:}

At the end of the study, economical efficiency for egg production was expressed as hen-production thought the study and calculated using the following equation: Economic efficiency $(\%)=(\mathrm{Net}$ return LE/Total feed cost LE) $\times 100$.

Statistical analysis:

Data were statistically analyzed using General Linear Models Procedure of the SPSS program (1997). Differences between treatments were subjected to Duncan's Multiple Range- test (Duncan, 1955). A factorial design $3 \times 2$ was used, considering the ME and CoQ10 levels as the main effects and the following model was used to study the effect of main factors and interaction between ME and CoQ10 on parameters investigated as follows: Yijk $=\mu+T i+R j+(T R) i j+e i j$ 
Where $:$ Yijk $=$ An observation; $\mu=$ overall mean $; \mathrm{T}=$ effect of $\mathrm{ME}$ level; $\mathrm{ME}=(1$ and 2 ); $R=$ effect of CoQ10 level; $j=(1,2$ and 3$)$; $\mathrm{TR}=$ effect of interaction between $\mathrm{ME}$ and CoQ10 ; and ejik= Experimental error.

\section{RESULTS AND DISCUSSION}

The effect of different levels of ME, CoQ10 and interaction between them on body weight for Sinai laying hens are shown in Table (2). Change body weight for Sinai laying hens was significantly increased by $1.89 \%$ for hens fed diet with low of energy (E2) than those fed diet with high level of energy (E1). No significant $(\mathrm{P} \geq 0.05)$ influence of $\mathrm{CoQ} 10$ on body weight for Sinai laying hens during experimental periods. Interaction between energy levels and Co enzyme Q10 had no significant effect $(\mathrm{P} \geq 0.05)$ on body weight at different ages Body weight gain was higher significantly $(\mathrm{P} \leq 0.05)$ for low energy (E2) than high energy (E1) by $9.55 \%$. The hens fed diets supplements with Co enzyme Q10 natural or syncretic had insignificantly $(\mathrm{P} \geq 0.05)$ effect, although the heights value of body weight gain was calculated with CoenzymeQ10 (n). Interaction between energy levels and Co enzymeQ10 sources had insignificantly ( $P \geq 0.05$ affected on body weight gain during the experimental periods. The low level of ME (E2) with CoQ10 (0) had insignificantly higher $(\mathrm{P} \geq 0.05)$ body weight gain than other treatments under condition of the study.

Regarding ME, this result disagreement with Balnave and Robinson (2000) who observed that body weight gain increased with increasing dietary ME level (2500, 2700 and $2900 \mathrm{kcal} \mathrm{ME} / \mathrm{kg}$ ) in the diet for Brown layer strains, this difference may be $\mathrm{du}$ to the usage stain in study. But, in respect of the effect of CoQ10, these results are consist with Geng et al., (2004) who found that BW gain, was not influenced significantly by CoQ10 supplementation in broilers.

Laying performance:
Data in Table (3) showed that egg weight affected by different levels of energy, supplementation of enzyme Q10 and their interactions. Results demonstrated that there is significant $(\mathrm{P} \leq 0.05)$ difference between different levels of energy on egg weight for all experimental periods except age the period 25-28 week of age. Hens receiving low energy feed (E2) recorded the highest egg weight $34.86 \mathrm{gm}$ during age from (25-40) weeks of age compared with high energy diet (E1) (42.72gm). Concerning the effects of different sources of Co enzyme Q10 on egg weight no significance effect $(\mathrm{P} \geq 0.05)$ between Dietary CoenzymeQ10 during all experimental periods except the period from 25-28 weeks of age, where, it was differ significantly. Egg weight was significantly increased by $2.37 \%$ for hens fed diet supplemented with CoenzymeQ10 $_{(\mathrm{s})}$ than those fed diet supplemented with Co enzymeQ10 (n). Egg weight for hens fed diet with Co enzymeQ10 $(0)$ was higher $(\mathrm{P} \leq 0.05)$ than those fed diet with Co enzyme Q10(n) at ages of (25-28) weeks, but these increasing of weight was not significant . Interaction between energy levels and sources of Co enzyme Q10 had no significant effect $(\mathrm{P} \geq 0.05)$ on egg weight.

Hens fed low energy diet had significantly higher $(\mathrm{P} \leq 0.05)$ egg number by $7.66 \%, 14.1 \%, 25.02 \%$ and $5.99 \%$ than others fed diet with high level of energy during 29-32, 33-36, 37-40 and 25-40 weeks of age respectively (Table 3 ). On the other hand, egg number for hens with (E1) was significantly higher than hens with (E2) during (25-28) weeks of age. Hens fed diets supplemented with $\mathrm{C} 0 \mathrm{Q10}(\mathrm{s})$ had significantly higher egg number than those fed diets with Co Q10 $0_{(0)}$ and Co enzymeQ10 $(\mathrm{n})$ during experimental periods. The improvement of egg number was $11.98 \%, 2.52 \%, 4.87 \%, 10.32 \%$ and $8.14 \%$ for hens received diet with Co enzymeQ10 (s) as compared to those fed diet with Co enzymeQ10(n) during (25-28), ( 
29-32), (33-36), (37-40), and ( 25-40) weeks of age respectively, while this improvement of egg number was $5.97 \%, 5.29 \%, 7.01 \%, 4.04 \%$ and $7.22 \% \%$ for hens received diet with Co $\mathrm{Q} 10_{(\mathrm{s})}$ as compared to those fed diet with CoQ10 $0_{(0)}$ during (25-28), (29-32),(33-36), (37-40) , and ( 25-40) weeks of age respectively. Interaction between hens fed diet with different levels of energy and different sources of CoQ10 had no significant $(\mathrm{P} \geq 0.05)$ effect on egg number during different experimental periods expect (3740) and (25-40) weeks of age which hens with CoQ10 $($ s) had higher egg number than other treatments at different levels of energy.

Egg production \% during most interval periods and overall experimental period was significantly affected by levels of energy and sources of CoQ10 (Table 4). The differences between hens fed diet with different level of energy were highly significant. The improvement of egg production \% for the group fed $2660 \mathrm{Kcal}$ $\mathrm{ME} / \mathrm{Kg}$ diet was significantly increased by $9.57 \%$ as compared to those fed $2760 \mathrm{Kcal}$ $\mathrm{ME} / \mathrm{Kg}$ diet.

On the other hand, supplemented diet with CoQ10 had significant $(\mathrm{P} \leq 0.05)$ effects on egg production\% during all the experimental periods except of (29-32) and (33-36) weeks of age (Table 4). The group fed diet with CoQ10 $(\mathrm{s})$ had significantly $(\mathrm{P} \geq 0.05)$ increasing egg production\%. Egg production $\%$ was insignificantly $(\mathrm{P} \geq 0.05)$ affected due to the interaction between level of energy and sources of CoQ10 in the diet during all experimental periods, except of the periods (37 -40) and (25 - 40) weeks which showed significant effect. The best records of egg production $(65.37 \%)$ occurred by the group fed diet contained ME $2660 \mathrm{Kcal} / \mathrm{Kg}$ and CoQ10 (s) followed by those fed diets containing $2660 \mathrm{Kcal}$ $\mathrm{ME} / \mathrm{Kg}$ with CoQ10 (n) during the overall experimental period ( 25-40)weeks of age.

A significant $(\mathrm{P} \leq 0.05)$ difference was observed among the experimental groups in egg mass per hen during experimental periods due to varying ME levels in the diet (Table 4). Egg mass was improved $(\mathrm{P} \leq 0.05)$ for the group fed $2660 \mathrm{Kcal}$ $\mathrm{ME} / \mathrm{Kg}$ diet by $12.54 \%$ as compared to hens fed recommended ME diet low ME during overall experimental periods.

On the other hand, hens fed dietary CoQ10 (s) in the diet had significantly $(\mathrm{P} \leq 0.05)$ higher egg mass by $5.76 \%$ and $8.4 \%$ than dietary CoQ10 (o) and CoeQ10 (n) respectively during the all experimental periods. Egg mass was significantly $(\mathrm{P} \leq 0.05)$ affected due to the interaction between energy levels and sources of CoQ10 in the diet during all experimental periods, except at the period (29-32) weeks which showed insignificant $(\mathrm{P} \leq 0.05)$ effect. In general the best $(\mathrm{P} \leq 0.05)$ egg mass (3210.8) was recorded by the group fed diet contained $2660 \mathrm{Kcal} / \mathrm{Kg}$ and CQ10(s) during the overall experimental periods.

Initially, these results in line with Ciftci et al. (2003) who found that decreasing the energy content of feed from 2,751 to 2,641 $\mathrm{kcal}$ of $\mathrm{ME} / \mathrm{kg}$ increased the laying rate from 86.44 to $88.27 \%$. But, Mathlouthi et al. (2002) reported that the best laying rates at was recorded when layers fed dietary $2,753 \mathrm{kcal}$ of ME/ $\mathrm{kg}$ of diet compared with $2,653 \mathrm{kcal}$ of $\mathrm{ME} / \mathrm{kg}$ of feed. Responses of insignificant egg weight to changes in feed energy content are parallel to the find of (Mathlouthi et al., 2002 and Ciftci et al., 2003). However, some authors have reported significant, although small, increases in egg weight caused by increased dietary energy (Peguri and Coon, 1991).

Regarding supplementation CoQ10 and interaction between ME and CoQ10, the likely reasons for the improvement in laying performance results from supplementation $7.5 \mathrm{mg}$ CoQ10(s) and interaction between low dietary ME level +7.5 mg CoQ10(s) are discussed by the study of Geng and Gue (2005) who suggested that supplementation CoQ10 may be improved the hepatic mitochondrial 
function and some respiratory chain-related enzymes activities. Coenzyme Q10 as a lipid-soluble compound present in endomembrane of cells as well as in mitochondria, it takes part in the mitochondrial respiratory chain, accepts and transports electrons to oxygen, and at the same time the proton gradient promotes ATP synthesis (Ernster and Dallner, 1995). The study by Kikusato et al., (2015) indicates that dietary supplementation with CoQ10 attenuates the muscular oxidative damage, suggesting that this may be due to the suppression of mitochondrial reactive oxygen species (ROS) production. Bhagavan and Chopra (2006) reported that two major functions are attributed to CoQ10: it acts as an electron carrier in the mitochondrial respiratory chain and as a lipid-soluble antioxidant. CoQ10 efficiently prevents lipid, protein, and DNA from oxidation, and is continuously regenerated by an intracellular reduction system in animal tissues (Andre'e et al., 1998). In addition, the amount of CoQ10 in many membranes is from three to 30 times the tocopherol content (Turunen et al., 1999). Since much of the coenzyme $Q$ in cell membranes is in the quinol form (Takahashi et al., 1993), it can be a very effective antioxidant (Quinn et al., 1999). Even more important is the presence of enzymes in all membranes which can reduce any coenzyme $\mathrm{Q}$ quinone radical generated by reaction with lipid or oxygen radicals. Furthermore, CoQ10 is also known as a very effective antioxidant (Bentinger et al., 2007), protecting against lipid peroxidation, DNA, and protein oxidation and capable of functioning synergistically with other antioxidants (Challem, 2005).

Feed intake and feed conversion ratio:

Feed intake was significantly $(\mathrm{P} \leq 0.05)$ affected during some experimental periods due to varying levels of energy and Coenzyme Q10 and their interaction in the diet (Table5). Hens fed $2760 \mathrm{Kcal} / \mathrm{kg}$ diet consumed lower feed than those fed 2660 $\mathrm{Kcal} / \mathrm{Kg}$ during the (25-40) weeks of age. Daily feed intake was decreased by about $7.49 \%$ for hens fed $2760 \mathrm{Kcal} / \mathrm{Kg}$ as compared to those fed $2660 \mathrm{Kcal} / \mathrm{Kg}$ during the overall experimental period.

Also, feed intake was significantly $(\mathrm{P} \leq 0.05)$ affected due to supplementation of Co Q10 to hen's diets during all studied periods except (29-32) weeks of age (Table5). The hens fed diet with CoQ10(s) had the highest amount of feed intake comparing with those fed the control and CoQ10 (n) diets during overall experimental period. The increment in feed intake was $3.28 \%$ for hens fed diet with C0Q10 (s) as compared to control, while the feed intake decreased by $0.43 \%$ for hens fed diet with CoenzymeQ10 (n) than the control group. Interaction between energy level and sources of CoQ10 supplementation had significantly $(\mathrm{P} \leq 0.05)$ affected on fed intake during all experimental period except (25-28) weeks of age. Hens fed diet with low energy had higher $(\mathrm{P} \leq 0.05)$ fed intake than high energy at different sources of CoQ10 supplementation during all experimental periods. Hens fed diets contain $2660 \mathrm{Kcal} / \mathrm{Kg}+\mathrm{CoQ} 10_{(\mathrm{s})}$ recorded higher $(\mathrm{P} \leq 0.05)$ amount of feed intake during (25-40) weeks of age than control diet.

Feed conversion ratio was significantly $(\mathrm{P} \leq 0.05)$ affected by energy level in the diet during all experimental periods except (29-32) and (37-40) weeks of age (Table5). It is noticed that feed conversion was decreased by $6.20 \%$ for hens fed diets with $2760 \mathrm{Kcal} / \mathrm{Kg}$ than $2660 \mathrm{Kcal} / \mathrm{Kg}$ during the overall experimental periods (25-40) weeks of age. Hens fed diet supplementation with CoQ10 was insignificantly $(\mathrm{P} \geq 0.05)$ affected on feed conversion during all experimental period except (25-28) and (37-40) weeks of age which showed significantly $(\mathrm{P} \leq 0.05)$ influence. Feed conversion ratio was not significantly $(\mathrm{P} \geq 0.05)$ affected by the interaction between energy level and Co 
Q10 sources during all the experimental periods except during (37-40) weeks of age which was significantly affected. Hens fed diet contain low energy had the best $(\mathrm{P} \leq 0.05)$ feed conversion than high level energy as a result of supplementation of Co Q10 (s) or Co Q10 (n) to diet during the overall experimental period.

Regarding the effect of ME on feed intake, hens could fit their feed intake to satisfy their energy requirements; then, an increase in energy concentration leading to a reduced feed intake (Perez-Bonilla et al., 2012) while increasing dietary protein could increase (Gunawardana et al., 2008) or have no effect (Mohiti-Asli et al., 2012) on feed intake. According to these results the feed consumption was increased by decreasing ME content, where with decreasing dietary energy levels from 2760 to $2660 \mathrm{Kcal} / \mathrm{Kg}$ diet, feed intake increased from 96.67 to $140.5 \mathrm{~g} / \mathrm{hen} /$ day, therefore, a decrease of $100 \mathrm{kcal} / \mathrm{kg}$ dietary energy increased feed intake by $8.1 \%$. In addition, this is in agreement with Harms et al. (2000) who showed that hens fed the diets containing $2519 \mathrm{kcal} / \mathrm{kg}$ had $8.5 \%$ more feed intake than hens fed the diets containing $2798 \mathrm{kcal} / \mathrm{kg}$.

The present study illustrated that there were differences in dietary energy required to produce one gram egg among hens fed two dietary energy levels (control and 2660 $\mathrm{Kcal} / \mathrm{Kg}$ diet) as shown in Table (4) where, decreasing dietary energy level from 2760 to $2660 \mathrm{kcal} / \mathrm{kg}$, hens adjusted feed intake from 96.67 to $104.5 \mathrm{~g} / \mathrm{hen} /$ day, so that 11.09 and $10.27 \mathrm{Kcal} /$ day was used to produce one gram egg for hens fed diet 2760 and $2660 \mathrm{kcal} / \mathrm{Kg}$ diet respectively. Such finding is to be expected, as hens adjust feed intake when ME content decreasing to achieve a constant energy intake, but this was only up to decreasing dietary energy $100 \mathrm{Kcal} / \mathrm{Kg}$ diet as compared to the control diet in respect of laying performance. These result are consist with Wu et al.(2005) who reported that when dietary energy level increased from 2719 to $2956 \mathrm{kcal} / \mathrm{kg}$, hens adjusted feed intake from 107.6 to $101.1 \mathrm{~g} / \mathrm{hen} /$ day so that the same amount of dietary energy $(5.8 \mathrm{kcal})$ was used to produce one gram egg. In addition, the results is consist with Gunawardana et al. (2009) who found that as dietary energy increased feed intake would decrease Also, it seems from the present results that decreasing dietary energy to $2660 \mathrm{Kg} / \mathrm{Kg}$ diet resulted in a significant improve to feed conversion by about $6.61 \%$ comparing with the control diet. Similarly, Wu et al.(2005) reported that as dietary energy content increased from 2719 to $2956 \mathrm{kcal} / \mathrm{kg}$, feed conversion linearly decreased from 2.14 to 1.97 (g feed/g egg), resulting in a net decrease of $7.94 \%$. This difference relating to feed conversion values could be attributed to differences in strain of bird's age, amount of decreasing in $\mathrm{ME}$ and housing system. According to this study, the economical level of energy depends on the feed intake, feed conversion and cost of feed, and it is different about the recommendation (2750 $\mathrm{Kcal} / \mathrm{kg}$ ) where the results illustrated that $2660 \mathrm{Kcal} / \mathrm{Kg}$ diet was the economical level of ME.

Egg quality:

The results in Table (6) showed that insignificant $(\mathrm{P} \geq 0.05)$ effect of diets contained different levels of ME, Co Q10 and interaction between $\mathrm{ME}$ and Co Q10 on shape index, shell weight $\%$, yolk and albumin weight $\%$, yolk index and Haugh units. However, significant $(\mathrm{P} \leq 0.05)$ effect on shell thickness was observed due to supplementation of CoQ10(s) irrespective the level of ME in the diet, also the interaction between supplementation CoQ10(s) 0 Or CoQ10 (n) + the low level of ME significantly $(\mathrm{P} \leq 0.05)$ increased the shell thickness comparing with the control diet and other treatments. On the other hand, the interaction between E2 and CoQ10 (0) resulted in the lower value of shell thickness than control and other diets.

This is in line with findings of Tercic et al. (2011) who found that the CoQ10 
dietary supplementation did not affect on albumen height, Haugh units and shell weight, whereas was shown no significant differences in shell thickness compared with control group. Williams (1992) concluded that albumen quality is not greatly influenced by bird nutrition. However, a number of nutritional factors have been reported to affect albumen quality. Also, Kamisoyama et al., (2010) found that egg quality did not influenced by CoQ10 supplementation.

Profile fatty acids in egg yolk: Results of egg yolk analysis for polyunsaturated fatty acids (PUFA) contents are presented in Table (8). Polyunsaturated fatty acids showed different response to dietary treatments where, yolk of hens fed diet contained E2 $(2660 \mathrm{Kcal} / \mathrm{Kg}$ diet $)$ showed significantly $(\mathrm{P} \leq 0.05)$ higher percentage of $\mathrm{C} 18: 2 \omega 6$ and C18:406 by about 18.8 and $26.9 \%$ than yolk of hens fed the control diet, while the percentage of C18:203 was not influenced by decreasing the ME in the diet.

Regarding the effect of CoQ10 supplementation, the percentage of C18:2 $\omega 6$ and $\mathrm{C} 18: 2 \omega 3$ showed similar trends but varied in the magnitude of change as both of them from diet supplementation with $7.5 \mathrm{mg} / \mathrm{Kg} \mathrm{CoQ} 10$ (n) being significantly $(\mathrm{P} \leq 0.05)$ higher than those of the diet with7.5 mg/Kg CoQ10 and control diet. On the other hand the percentages of $\mathrm{C} 20: 4 \omega 6$ was significantly $(\mathrm{P} \leq 0.05)$ reduced in response to the diet contained with7.5 $\mathrm{mg} / \mathrm{Kg} \quad \mathrm{CoQ} 10_{(\mathrm{s})}$ comparing with the control and CoQ10 (n).

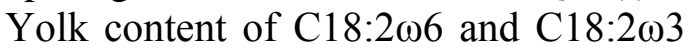
were affected by the interaction between ME and CoQ10 investigated. Where, yolks of hens fed diet ME 2760 or $2660 \mathrm{Kcal} / \mathrm{Kg}$ diet+ $7.5 \mathrm{mg} / \mathrm{Kg}$ CoQ10 (n) recorded the best $(\mathrm{P} \leq 0.05)$ percentage of $\mathrm{C} 18: 2 \omega 6$ and C18:203 as compared to control and other groups. Also, the interaction between ME $2760 \mathrm{Kcal} / \mathrm{Kg}$ diet and $7.5 \mathrm{mg} / \mathrm{Kg} \mathrm{CoQ} 10$ (s) recorded significantly $(\mathrm{P} \leq 0.05)$ the lowest value of $\mathrm{C} 20: 4 \omega 6$ compared to the control diet

In fact, the results in the current study illustrated that the egg is an excellent source of essential fatty acid mainly belonging to the $n-6$ series (linoleic and arachidonic acids) and also contains moderate amounts of $n-3$ polyunsaturated fatty acids (PUFA), which are essential for many biological functions. The previous remarks about fatty acids were confirmed, and the increase of total n- 6 and n-3 fatty acids was more evident in the yolks of hens fed diet contained ME 2660Kcak/Kg diet+7.5mg CoQ10 (n) comparing with the control diet, where the percentage of $n-6$ was $14.62 \%$ vs $7.28 \%$ as well as the count of $\mathrm{n}-3$ was $0.37 \%$ vs $0.11 \%$. From the nutritional standpoint, the increment in percentage of essential fatty acids

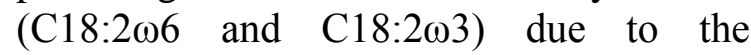
supplementation $7.5 \mathrm{mg} / \mathrm{Kg} \mathrm{CoQ} 10$ (n) is to be expected, as soybean oil is rich in $\mathrm{n}-6$ PUFA (Simopoulos and Robinson, 1998), the most common lipid supplements in commercial vegetable diets is soybean, mostly for economical and nutritional reasons (Meluzzi et al., 2001). Enrichment of hen diets with sources rich in linoleic acid has resulted in production of eggs with significantly increased levels of yolk linolenic acid (LNA) and small but significantly higher increases in the 20carbon family of PUFA n- 3 (Cherian and Sim, 1991). In addition, the diet contained ME $2760 \mathrm{Kcal} / \mathrm{Kg}$ diet $+7.5 \mathrm{mg} \mathrm{CoQ} 10(5)$ significantly reduced the percentage of arachidonic acid, the decrease in arachidonic acid content could be important for human health, as this acid is a precursor of some pro inflammatory eicosanoids (British Nutrition

Foundation, 1992). This phenomenon is probably due to the greater utilization of $\Delta$ 6-desaturase in the n-3 fatty acid pathway with respect to the n-6 pathway, as this enzyme acts in both pathways. High concentrations of dietary n-3 fatty acids reduce the activity of the enzyme in the $n-6$ 
pathway and the conversion of linoleic into arachidonic acid (Meluzzi, et al., 2000). Also, Hasegawa et al. (2009) reported that coQ10 can be promising candidates for feed additive to improve egg quality.

Yolk content of saturated fatty acids (SFA) was significantly affected by the dietary ME, where all USFA (C14:0, C16:0 and C18:0) were significantly decreased in response to the low dietary ME compare to the control diet. While, the percentage of C14:0 was not affected by dietary supplementation of CoQ10, But the C16:0 and $\mathrm{C} 18: 0$ content significantly $(\mathrm{P} \leq 0.05)$ reduced by the diet contained $7.5 \mathrm{mg}$ CoQ10 (n) comparing with the control diet. The interaction between ME and CoQ10 significantly influenced on $\mathrm{C} 14: 0$ and C16:0 as all treatments caused significant decrease $(\mathrm{P} \leq 0.05)$ in yolk content of these acids except for the yolks from hens fed diet with ME $2760 \mathrm{Kcal}+7.5 \mathrm{mg}$ CoQ10(s) $/ \mathrm{Kg}$ diet, on the other hand, no significant $(\mathrm{P} \geq 0.05)$ influence of interaction on $\mathrm{C} 18: 0$ as compared to the control diet.

In respect of monounsaturated fatty acids (MUFA) the results showed that yolks of hens fed the low level of ME had 4.53\% higher $\mathrm{C} 18: \omega 9$ than control diet, also both $\mathrm{C} 16: 1 \omega 7$ and $\mathrm{C} 18: 1 \omega 7$ content had the same manner. In contrast, the low level of ME significantly $(\mathrm{P} \leq 0.05)$ reduced yolk content of $\mathrm{C} 16: 1 \omega 9$ as compared to the control diet. The percentage of

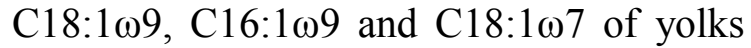
from diet supplemented with $7.5 \mathrm{mg}$ $\mathrm{CoQ10}_{(\mathrm{s})} / \mathrm{Kg}$ diet were significantly $(\mathrm{P} \leq 0.05)$ higher than yolks of hens fed the control diet. But, the C16:1 107 percentage significantly $(\mathrm{P} \leq 0.05)$ decreased in yolks from hens fed diet with7.5mg CoQ10 $(\mathrm{s}) / \mathrm{Kg}$ diet comparing with the control diet. Also, the results showed that yolks from hens fed diet contained ME2760Kcal $/ \mathrm{Kg}+7.5 \mathrm{mg}$ CoQ10 $(\mathrm{s})$ resulted in a significant $(\mathrm{P} \leq 0.05)$ decrease in $\mathrm{C} 16: 1 \omega 7$ compared to the control and other groups. While, yolks of hens fed the low level of $\mathrm{ME}+7.5 \mathrm{mg}$ CoQ10 (n) had the highest $(\mathrm{P} \leq 0.05)$ value of
C18:1 $\omega 9$ by about $13.15 \%$ comparing with the control. On the other hand, no significant $(\mathrm{P} \geq 0.05)$ influence of interaction between dietary ME and CoQ10 supplementation on the percentage of

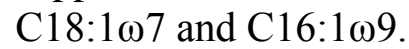

Regarding the results of SFA/PUFA ratio, they indicated that all treatments did not actually differ $(\mathrm{P} \geq 0.05)$ from control diet in the value of SFA/PUFA ratio except for the diet contain low ME, $7.5 \mathrm{mg}$ CoQ10(n) , and the diet contain low ME $+7.5 \mathrm{mg}$ CoQ10(s) or $7.5 \mathrm{mg}$ CoQ10(n) where, these diets was significantly $(\mathrm{P} \leq 0.05)$ lower in $\mathrm{SFA} / \mathrm{UPFA}$ ratio than control. While, the other diets were similar as compared to the control diet. American Heart Association (1996) has recommended a ratio of $1 / 1$, as several nutritional studies have reported the relationship between SFA and the risk of cardiovascular diseases. The reduction in C18:0 by the diets with E2, CoQ10(s) or (n) and $\mathrm{E} 2+\mathrm{CoQ} 10_{(\mathrm{s})}$ or (n) could indicate an additional health advantage for these eggs, as $\mathrm{C} 18: 0$ is considered hyper cholesterol emic, although much less than C16:0 (Katan et al., 1995). Compared with the control diet, inclusion of CoQ10 with low level of ME in diets at $7.5 \mathrm{mg} / \mathrm{Kg}$ improved the FA profile as evidenced by the relationship of SFA/ PUFA.

The hematology parameters:

Results concerning the changes in white blood cells (WBC) count, differential leucocytes counts and viability of hens in response the diets contained different levels of ME, CoQ10 and interaction between them are presented in Table (7). It is evident that WBC count was significantly affected by the level $\mathrm{ME}$ in layer diet where, hens fed the requirements of $\mathrm{ME}$ had the highest value of WBC count compared to those fed the low level of ME. Also, the lower level of ME caused a significant $(\mathrm{P} \leq 0.05)$ decrease to both heterophil (H) \% and heterophil / lymphocyte (L) ratio, While, the lymphocyte $\%$ and viability were not 
affected by decreasing dietary ME. In respect of the effect of CoQ10 on blood hematology, the WBC count and viability were not affected by supplementation CoQ10 to the diet, while the heterophil \% and $\mathrm{H} / \mathrm{L}$ ratio were significantly $(\mathrm{P} \leq 0.05)$ increased due to the diet supplemented with7.5 mg/Kg CoQ10(s) compared to the control diet. No significant $(\mathrm{P} \geq 0.05)$ influence of interaction between dietary ME and CoQ10 supplementation on blood hematology traits and viability\%.

These results may be supported by Fathi (2015) who showed that blood hematocrit and hemoglobin (hematology traits) were not affected by supplementation $40 \mathrm{mg} / \mathrm{Kg}$ CoQ10 to dietary of broilers with pulmonary hypertension syndrome. But the same author found that viability decreased by CoQ10 supplementation. From these results it could be mentioned that under conditions of the current study, the major function of dietary CoQ10 supplementation that it is an electron carrier in the mitochondrial respiratory chain more than as a lipid soluble antioxidant (Bhagavan and Chopra 2006) thus it acts as compensating the decrease in dietary ME.

\section{Nutrients digestibility:}

The results in Table (10) indicated that no alteration among the nutrients digestibility due to the decreasing $\mathrm{ME}$ content from 2760to $2660 \mathrm{Kcal} / \mathrm{Kg}$ diet except for the digestion coefficient of ether extract (EE) digestibility where EE significantly $(\mathrm{P} \leq 0.05)$ decreased by the diet contained ME 2660 compared to 2760 $\mathrm{Kcal} / \mathrm{Kg}$ diet. Also, the results illustrate that all values of nutrients digestibility and ash retention were nearly and no significant $(\mathrm{P} \geq 0.05)$ influence was observed as a results of supplementation CoQ10, however, the digestibility of EE tend to significantly $(\mathrm{P} \leq 0.05)$ increased for the diet supplemented with $7.5 \mathrm{mg}$ CoQ10 (n). Conversely, the birds fed diet with $7.5 \mathrm{mg}$ CoQ10 (n) recorded the lowest $(\mathrm{P} \leq 0.05)$ value of NFE than control by about $4.66 \%$.
On the other hand, supplementation of CoQ10 (s) insignificantly $\quad(\mathrm{P} \geq 0.05)$ increased both the digestibility of $\mathrm{OM}$ and NFE compared to the control diet.

It is clear from the results that digestion coefficient of all nutrients were not affected $(\mathrm{P} \geq 0.05)$ by the interaction between $\mathrm{ME}$ and CoQ10 with exception EE and NFE where the results showed that the interaction between ME 2760 or 2660 $\mathrm{Kcal} / \mathrm{Kg}$ diet and $7.5 \mathrm{mg}$ CoQ10 (n) resulted in a significant increase in EE while NFE was significantly $(\mathrm{P} \leq 0.05)$ increased by the interaction between ME $2760 \mathrm{Kcal} / \mathrm{Kg}$ diet and $7.5 \mathrm{mg}$ CoQ10 (n) by about $9 \%$ compared to control diet. Conversely, the interaction between the low level of $\mathrm{ME}$ and CoQ10 resulted in insignificantly $(\mathrm{P} \geq 0.05)$ improve in respect of digestibility $\mathrm{CF}$ and ash retention comparing with the control diet.

Generally, the decreasing ME content from 2760 to $2660 \mathrm{Kcal} / \mathrm{Kg}$ diet resulted in a significant $(\mathrm{P} \leq 0.05)$ increase in feed intake/ hen as shown in Table (5) thus results in the current study showed that no alteration among the nutrients digestibility results from the decreasing ME content in the diet where, According to $\mathbf{W u}$ et al. (2005) when dietary energy decreased from 2,956 to $2,719 \mathrm{kcal}$ of $\mathrm{ME} / \mathrm{kg}$, hens adjusted feed intake from 101.1 to 107.6 $\mathrm{g} / \mathrm{hen}$ per day to achieve a constant energy intake so that the same amount of dietary energy $(5.8 \mathrm{kcal})$ was used to produce $1 \mathrm{~g}$ of egg. But in our study, hens adjusted feed intake from 96.67 to $104.5 \mathrm{~g} / \mathrm{hen} /$ day, so that 11.09 and $10.27 \mathrm{Kcal} /$ day was used to produce one gram egg for hens fed diet 2760 and $2660 \mathrm{kcal} / \mathrm{Kg}$ diet respectively. In addition, with decreasing dietary energy, nutrient intake such as protein, total sulfur amino acids and lysine linearly increased where, nutrient contents, except dietary energy level as a main factor, were the same values. The increase of nutrient intake might explain why decreasing dietary energy levels from 2,760 to $2,660 \mathrm{kcal}$ of $\mathrm{ME} / \mathrm{kg}$ had no effect on nutrients 
digestibility and supports the hypothesis that this probably is an ideal energy/protein (lysine) ratio for optimal performance. In addition, the beneficial effect on digestibility of $\mathrm{CF}$ perhaps due to the low dietary ME resulted in increase the feed intake (Table 5) and consequently increase the consumption of crude fiber, this due to increase grinding activity of the gizzard together with a better mixing of digestive juices with the digesta attributable to the increase in antiperistaltic movements within the GIT, might explain the positive effects on the digestibility of crude fiber (Jiménez-Moreno et al., 2009).

The digestion coefficient of $\mathrm{CF}$ and ash retention closely correlated with the productive performance where, these traits were improved by supplementation $7.5 \mathrm{mg}$ CoQ10 $(\mathrm{s})$ to the diet contained low ME (2660 Kcal/Kg diet) this improvement may be attributed to the beneficial effect of CoQ10. Two major functions are attributed to this compound, namely as an electron carrier in the mitochondrial respiratory chain and as a lipid-soluble antioxidant (Bhagavan and Chopra 2006). These results agree with an earlier report by (Geng et al.,2004) who showed that the effective dose of CoQ10 may be as low as $20 \mathrm{mg} / \mathrm{kg}$, also who reported that CoQ10 protects the cell membrane and cell structure against peroxidation and thus more tolerant to the metabolic stress.

Economic efficiency (EE):

Results concerning the EE of egg production as influenced by the dietary treatments are shown in Table (11). The results illustrated that the low level of $\mathrm{ME}$ $(2660 \mathrm{Kcal} / \mathrm{Kg}$ diet) resulted in a significantly $(\mathrm{P} \geq 0.05)$ higher $\mathrm{EE}$ than the control by $8.81 \%$. Also, the greatest value of EE was produced by hens fed diet supplemented with $7.5 \mathrm{mg}$ CoQ10 $(\mathrm{s}) / \mathrm{kg}$ diet which was significantly $(\mathrm{P} \geq 0.05)$ higher than control by about $13.4 \%$. In contrast, hens fed diet with $7.5 \mathrm{mg}$ c0 Q10 (n) from 3\% soybean oil produced the lowest value of EE compared to the control diet. In respect of the interaction between $\mathrm{ME}$ and CoQ10, the greatest $(\mathrm{P} \geq 0.05)$ value of $\mathrm{EE}$ was produced by hens fed diet contained the low level of $\mathrm{ME}+7.5 \mathrm{mg}$ CoQ10 (s) / kg diet followed by the diet contained the requirement of $\mathrm{ME}+7.5 \mathrm{mg}$ CoQ10 (s) / kg diet. It is the most remarkable is that the hens fed diet contained $2760 \mathrm{kcal} \mathrm{ME}+7.5 \mathrm{mg}$ CoQ10 (n) / Kg diet.

\section{CONCLUSION}

The results in the current study illustrated that laying hens is quite convenient for fortification with CoQ10 and supplementation $7.5 \mathrm{mg}$ CoQ10 (s) $/ \mathrm{kg}$ diet contained low level of ME (2660 $\mathrm{Kcal} / \mathrm{Kg} / \mathrm{diet}$ ) could be used a functional feed additive in Sinai laying hens from 25 to 40 weeks of age which housed in laying cages to maximize the productive performance, economic efficiency and improve the internal egg quality in respect of the profile fatty acids. 
Table (1): Composition and calculated nutrients of experimental diets

\begin{tabular}{|c|c|c|c|c|c|c|}
\hline \multirow{3}{*}{$\begin{array}{c}\text { Diets } \\
\text { Ingredients }\end{array}$} & \multicolumn{6}{|c|}{ Dietary ME (Kcal/Kg diet) } \\
\hline & \multicolumn{3}{|c|}{ Control } & \multicolumn{3}{|c|}{ Low energy diet } \\
\hline & CoQ10 $(0)$ & CoQ10 $(\mathrm{s})$ & C0Q10(n) & $\operatorname{CoQ10}_{(0)}$ & $\operatorname{CoQ}_{10}(\mathrm{~s})$ & $\operatorname{COQ10}_{(\mathrm{n})}$ \\
\hline Yellow corn & 67.4 & 67.4 & 57.5 & 63.0 & 63.0 & 53.0 \\
\hline Soybean meal (44\%) & 22.15 & 22.15 & 21.15 & 21.0 & 21.0 & 20.35 \\
\hline Wheat bran & 0.8 & 0.8 & 8.7 & 6.35 & 6.35 & 14 \\
\hline Soybean oil & 0.0 & 0.0 & 3.0 & 0.0 & 0.0 & 3.0 \\
\hline Limestone & 7.5 & 7.5 & 7.5 & 7.5 & 7.5 & 7.5 \\
\hline Dicalcium phosphate & 1.5 & 1.5 & 1.5 & 1.5 & 1.5 & 1.5 \\
\hline Salt & 0.3 & 0.3 & 0.3 & 0.3 & 0.3 & 0.3 \\
\hline Premix $^{1}$ & 0.3 & 0.3 & 0.3 & 0.3 & 0.3 & 0.3 \\
\hline Dl-methionine & 0.05 & 0.05 & 0.05 & 0.05 & 0.05 & 0.05 \\
\hline Total & 100 & 100 & 100 & 100 & 100 & 100 \\
\hline \multicolumn{7}{|c|}{ Calculated nutritional values ${ }^{2}$} \\
\hline Crude protein $\%$ & 15.10 & 15.10 & 1510 & 15.10 & 15.10 & 15.16 \\
\hline ME (Kcal / Kg) & 2764 & 2764 & 2764 & 2663 & 2663 & 2664 \\
\hline Crude fat $\%$ & 2.93 & 2.93 & 5.85 & 2.96 & 2.96 & 5.88 \\
\hline Crude fiber $\%$ & 3.25 & 3.25 & 3.82 & 3.68 & 3.68 & 4.24 \\
\hline Calcium \% & 33.22 & 33.22 & 3.22 & 3.22 & 3.22 & 3.23 \\
\hline Av. phosphorus\% & 0.398 & 0.398 & 0.416 & 0.412 & 0.412 & 0.428 \\
\hline T. phosphorus $\%$ & 0.595 & 0.595 & 0.636 & 0.627 & 0.627 & 0.667 \\
\hline Methionine $\%$ & 0.328 & 0.328 & 0.322 & 0.326 & 0.326 & 0.322 \\
\hline Methionine + cystin $\%$ & 0.584 & 0.584 & 0.586 & 0.589 & 0.589 & 0.592 \\
\hline Lysine \% & 0.819 & 0.819 & 0.817 & 0.811 & 0.811 & 0.818 \\
\hline Price $(\mathrm{LE} / \mathrm{kg})^{3}$ & 292.46 & 292.68 & 309.47 & 288.98 & 289.2 & 306.98 \\
\hline
\end{tabular}

1 - Each $3 \mathrm{~kg}$ of Vit and Min. premix contains 100 million IUVit A;2 million IU Vit.D $; 10 \mathrm{~g}$ Vit.E; 1 g Vit. $\mathrm{K}_{3} ; 1 \mathrm{~g}$ Vit $\mathrm{B}_{1} ; 5$ g Vit $\mathrm{B}_{2} ; 10 \mathrm{mg}$ Vit. $\mathrm{B}_{12} ; 1.5 \mathrm{~g}$ Vit $\mathrm{B}_{6} ; 30 \mathrm{~g}$ Niacin $; 10 \mathrm{~g}$ Pantothenic acid ;1g Folic acid;50 mg Biotin ; $300 \mathrm{~g}$ Choline chloride; $50 \mathrm{~g}$ Zinc; $4 \mathrm{~g}$ Copper; $0.3 \mathrm{~g}$ Iodine ; $30 \mathrm{~g}$ Iron; $0.1 \mathrm{~g}$ Selenium; 60g Manganese ;0.1 g Cobalt; and carrier CaCO3 to $3000 \mathrm{~g}$.

2- According to feed composition Tables of animal and poultry feedstuffs used in Egypt (2001)

3- Price of one $\mathrm{kg}$ (LE) at time of experiment for different ingredients : yellow corn, 2.27; Soy been meal, 5.05; Corn gluten, 6.50; Wheat bran, 2.22; Olive cake, 0.80; sunflower meal, 2.75; Dicalcium, 4.55; limestone, 1.50; Vit. \& Min., 20.0; Na cl, 0.50 and Meth, 32.0 
Table (2): Effect of different levels of Metabolizable energy and Coenzyme Q10 on Body weight for Sinai laying hens

\begin{tabular}{|c|c|c|c|c|}
\hline \multirow{2}{*}{\multicolumn{2}{|c|}{ Factors }} & \multicolumn{3}{|c|}{ Variables } \\
\hline & & $\begin{array}{c}\text { Initial Body } \\
\text { weight }\end{array}$ & Final body weight & $\begin{array}{c}\text { Change body } \\
\text { weight }\end{array}$ \\
\hline \multicolumn{5}{|c|}{ Energy(ME) Kcal/Kg diet } \\
\hline E1 (2760) & & 1238.8 & $1553.7^{\mathrm{b}}$ & $314.9^{\mathrm{b}}$ \\
\hline $\mathrm{E} 2(2660)$ & & 1238.0 & $1583.0^{\mathrm{a}}$ & $345.0^{\mathrm{a}}$ \\
\hline$\pm \mathrm{SE}$ mean & & 4.29 & 7.12 & 7.12 \\
\hline Significant & & NS & $*$ & $*$ \\
\hline \multicolumn{5}{|l|}{ CoQ10 } \\
\hline \multicolumn{2}{|l|}{ C0 Q10 (o) } & 1237.3 & 1570.5 & 333.1 \\
\hline \multicolumn{2}{|l|}{ Co Q10 (s) } & 1241.3 & 1562.7 & 321.3 \\
\hline \multicolumn{2}{|l|}{ Co Q10 (n) } & 1236.5 & 1571.9 & 335.35 \\
\hline \multicolumn{2}{|l|}{$\pm \mathrm{SE}$ mean } & 5.27 & 8.72 & 8.71 \\
\hline \multicolumn{2}{|l|}{ Significant } & NS & NS & NS \\
\hline \multicolumn{5}{|l|}{ Interaction } \\
\hline \multirow{3}{*}{$\frac{8}{\stackrel{8}{~}}$} & C0Q (0) & 1234.7 & 1545.9 & 311.3 \\
\hline & $\operatorname{CoQ}\left(7.5_{s}\right)$ & 1244 & 1554.3 & 310.3 \\
\hline & $\operatorname{CoQ}\left(7.5_{n}\right)$ & 1237.7 & 1560.7 & 323.1 \\
\hline \multirow{3}{*}{ 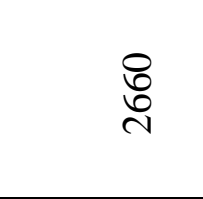 } & COQ (0) & 1240. & 1595.0 & 355.0 \\
\hline & $\operatorname{CoQ}\left(7.5_{s}\right)$ & 1238.7 & 1571.0 & 332.3 \\
\hline & $\operatorname{CoQ}(7.5 n)$ & 1235.3 & 1583.0 & 347.6 \\
\hline \multicolumn{2}{|l|}{ \pm SE mean } & 7.43 & 12.33 & 13.32 \\
\hline \multicolumn{2}{|l|}{ Significant } & NS & NS & NS \\
\hline
\end{tabular}

SE mean $=$ standard error mean; $a, b$ :means in the same column bearing different superscripts are significantly different $(\mathrm{P} \leq 0.05)$. NS $=$ non-significant; ${ }^{*}=\mathrm{P} \leq 0.05$ 
Table (3): Egg weight and egg number of local Sinai hens fed diets containing different levels of Metabolizable energy(ME)and Coenzyme Q10

\begin{tabular}{|c|c|c|c|c|c|c|c|c|c|c|c|}
\hline \multirow{2}{*}{\multicolumn{2}{|c|}{ Factors }} & \multicolumn{5}{|c|}{ egg weight -Age(weeks) } & \multicolumn{5}{|c|}{ Egg number -Age(weeks) } \\
\hline & & $25-28$ & 29-32 & $33-36$ & $37-40$ & $25-40$ & $25-28$ & 29-32 & $33-36$ & $37-40$ & $25-40$ \\
\hline \multicolumn{12}{|c|}{ Energy(ME) $\mathrm{Kcal} / \mathrm{kg}$ diet } \\
\hline \multirow{4}{*}{\multicolumn{2}{|c|}{$\begin{array}{l}\text { E1 (2760) } \\
\text { E2 }(2660) \\
\pm \text { SE mean } \\
\text { Significant }\end{array}$}} & 39.1 & $42.09^{\mathrm{b}}$ & $44.47^{b}$ & $45.45 b$ & $42.72 b$ & $15.21^{\mathrm{a}}$ & $18.66 \mathrm{~b}$ & $16.05^{\mathrm{b}}$ & $12.55^{\mathrm{b}}$ & $62.48 \mathrm{~b}$ \\
\hline & & 39.61 & $43.13^{\mathrm{a}}$ & $45.88^{\mathrm{a}}$ & $47.46 \mathrm{a}$ & $43.86 a$ & $14.28^{\mathrm{b}}$ & $20.09 \mathrm{a}$ & $18.31^{\mathrm{a}}$ & $15.69^{\mathrm{a}}$ & $68.47 \mathrm{a}$ \\
\hline & & 0.20 & 0.32 & 0.36 & 0.40 & 0.36 & 0.17 & 0.24 & 0.26 & 0.19 & 0.48 \\
\hline & & NS & $*$ & $*$ & $*$ & $*$ & $*$ & * & * & $*$ & * \\
\hline \multicolumn{12}{|c|}{ Co Q10 mg/Kg diet } \\
\hline \multirow{5}{*}{\multicolumn{2}{|c|}{$\begin{array}{l}0 \\
7.5 \mathrm{mg}(\mathrm{s}) \\
7.5 \mathrm{mg}(\mathrm{n}) \\
\pm \text { SE mean } \\
\text { Significant }\end{array}$}} & $39.7^{\mathrm{a}}$ & 43.11 & $\overline{45.51}$ & 46.68 & 43.75 & $14.72^{\mathrm{b}}$ & $18.87^{\mathrm{b}}$ & $16.68^{b}$ & $13.86 \mathrm{~b}$ & $64.11 b$ \\
\hline & & $39.59^{\mathrm{a}}$ & 42.31 & 44.67 & 45.97 & 43.1 & $15.6^{\mathrm{a}}$ & $19.87^{\mathrm{a}}$ & $17.85^{\mathrm{a}}$ & $15.42 \mathrm{a}$ & $68.74 \mathrm{a}$ \\
\hline & & $38.67^{\mathrm{b}}$ & 42.41 & 45.36 & 46.72 & 43.03 & $13.93^{\mathrm{c}}$ & $19.38^{\mathrm{ab}}$ & $17.02^{\mathrm{ab}}$ & $13.07 \mathrm{c}$ & $63.56 \mathrm{~b}$ \\
\hline & & 0.24 & 0.40 & 0.44 & 0.49 & 0.45 & 0.21 & 0.30 & 0.32 & 0.23 & 0.59 \\
\hline & & $*$ & NS & NS & NS & NS & $*$ & $*$ & $*$ & $*$ & $*$ \\
\hline \multicolumn{12}{|c|}{ Interaction CoQ10*Energy } \\
\hline \multirow{3}{*}{$\frac{\stackrel{8}{2}}{2}$} & C0Q $(0)$ & 40.01 & 43.25 & 45.45 & 46.4 & 43.66 & 15.43 & 18.4 & 15.93 & $13.29^{\mathrm{cd}}$ & $63.06^{\mathrm{c}}$ \\
\hline & $\operatorname{CoQ}\left(7.5_{\mathrm{s}}\right)$ & 39.34 & 41.13 & 43.44 & 44.52 & 41.95 & 16.1 & 18.83 & 16.23 & $13.77^{\mathrm{cd}}$ & $64.94^{\mathrm{bc}}$ \\
\hline & $\operatorname{CoQ}\left(7.5_{n}\right)$ & 37.94 & 41.88 & 44.52 & 45.44 & 42.56 & 14.1 & 18.73 & 15.9 & $10.60^{\mathrm{e}}$ & $59.44^{\mathrm{d}}$ \\
\hline \multirow{3}{*}{$\begin{array}{l}: \\
\text { : } \\
\text { N }\end{array}$} & C0Q (0) & 39.57 & 42.97 & 45.56 & 46.97 & 43.84 & 14.0 & 19.33 & 17.43 & $14.43^{\mathrm{bc}}$ & $65.17^{\mathrm{bc}}$ \\
\hline & $\operatorname{CoQ}\left(7.5_{\mathrm{s}}\right)$ & 39.84 & 43.48 & 45.90 & 47.41 & 44.25 & 15.1 & 20.9 & 19.47 & $17.09^{\mathrm{a}}$ & $72.55^{\mathrm{a}}$ \\
\hline & $\operatorname{CoQ}\left(7.5_{n}\right)$ & 39.41 & 42.94 & 46.19 & 48.01 & 43.49 & 13.77 & 20.03 & 18.04 & $15.54^{\mathrm{b}}$ & $67.68^{b}$ \\
\hline \multicolumn{2}{|c|}{ \pm SE mean } & 0.34 & 0.56 & 0.62 & 0.70 & 0.63 & 0.30 & 0.42 & 0.45 & 0.33 & 0.84 \\
\hline \multicolumn{2}{|c|}{ Significant } & NS & NS & NS & NS & NS & NS & NS & NS & * & $*$ \\
\hline
\end{tabular}


Table (4): Egg production and egg mass of laying hens fed diets containing different levels of Metabolizable energy and Coenzyme Q10

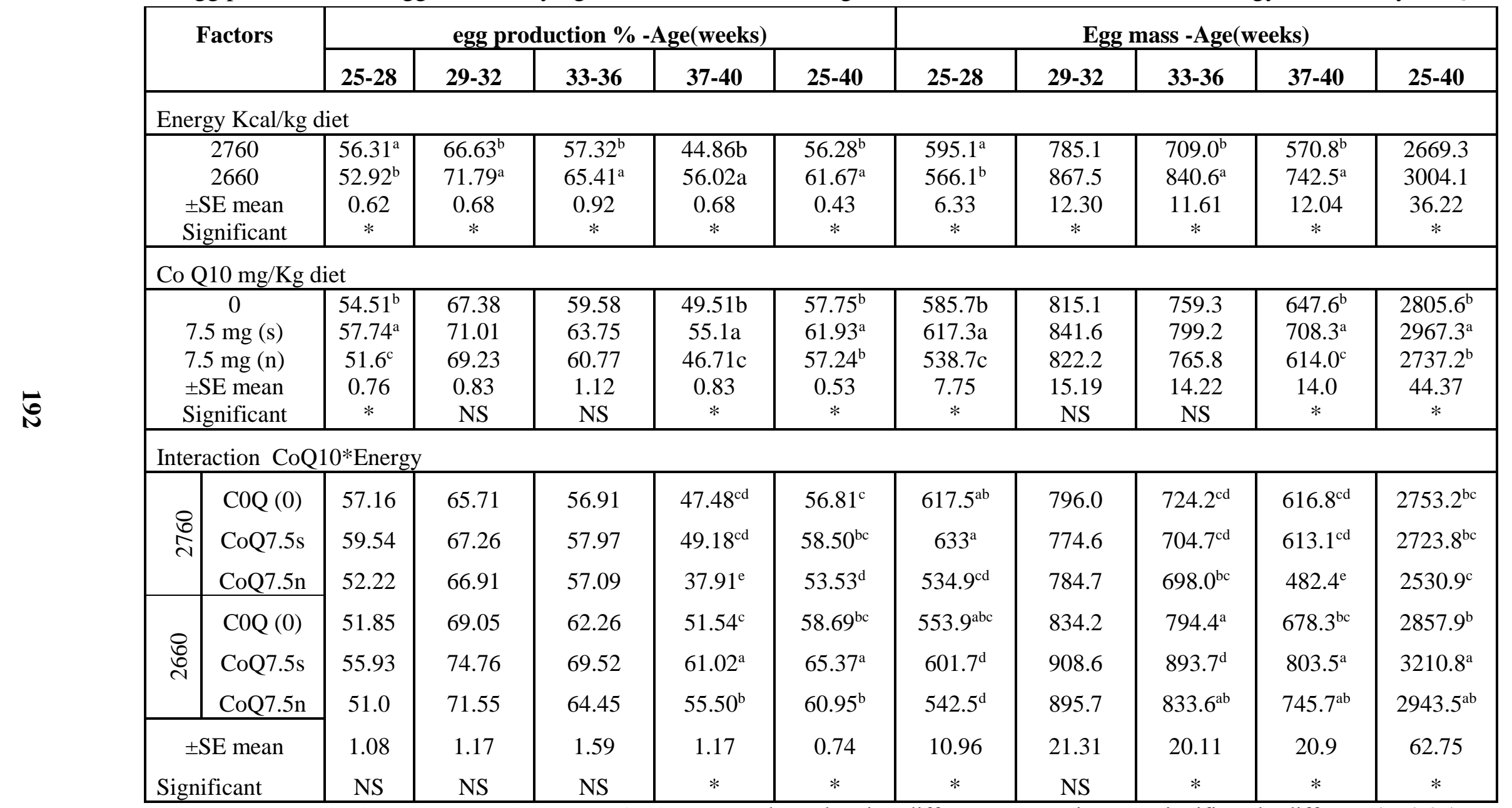

SE mean= standard error mean; a,b,c :means in the same column bearing different superscripts are significantly different $(\mathrm{P} \leq 0.05) \quad \mathrm{NS}=$ nonsignificant $; *=\mathrm{P} \leq 0.05$ 
Table (5): Feed intake and feed conversion ratio of hens fed diets containing different levels of Metabolizable energy and Coenzyme Q10

\begin{tabular}{|c|c|c|c|c|c|c|c|c|c|c|c|}
\hline \multirow{2}{*}{\multicolumn{2}{|c|}{ Factors }} & \multicolumn{5}{|c|}{ Feed intake / hen -Age(weeks) } & \multicolumn{5}{|c|}{ Feed conversion -Age(weeks) } \\
\hline & & $25-28$ & 29-32 & 33-36 & $37-40$ & $25-40$ & $25-28$ & 29-32 & $33-36$ & $37-40$ & $25-40$ \\
\hline \multicolumn{12}{|c|}{ Energy $\mathrm{Kcal} / \mathrm{kg}$ diet } \\
\hline & 760 & $93.12 b$ & $94.98^{\mathrm{b}}$ & 96.54 & $102.04^{\mathrm{b}}$ & $96.67 \mathrm{~b}$ & $4.24^{\mathrm{b}}$ & 3.39 & 3.82 & 5.07 & $4.03^{\mathrm{a}}$ \\
\hline & 2660 & $96.24 \mathrm{a}$ & $106.0^{\mathrm{a}}$ & 105.05 & $110.7^{\mathrm{a}}$ & $104.5 \mathrm{a}$ & $4.6 \mathrm{a}$ & 3.43 & 3.51 & 4.12 & $3.78^{\mathrm{b}}$ \\
\hline & mean & 0.58 & 0.42 & 0.48 & 0.63 & 0.35 & 0.03 & 0.05 & 0.05 & 0.09 & 0.05 \\
\hline Sig & nificant & $*$ & $*$ & $*$ & $*$ & $*$ & $*$ & NS & $*$ & NS & $*$ \\
\hline \multicolumn{12}{|c|}{ Co Q10 mg/Kg diet } \\
\hline \multirow{5}{*}{\multicolumn{2}{|c|}{$\begin{array}{c}0 \\
7.5 \mathrm{mg}(\mathrm{s}) \\
7.5 \mathrm{mg}(\mathrm{n}) \\
\pm \text { SE mean } \\
\text { Significant } \\
\end{array}$}} & $95.11 b$ & 100.81 & 99.13 & $103.46^{\mathrm{c}}$ & $99.63^{\mathrm{b}}$ & $4.40^{\mathrm{b}}$ & 3.47 & 3.66 & $4.38^{\mathrm{a}}$ & 3.95 \\
\hline & & $97.85 \mathrm{a}$ & 101.07 & 103.33 & $109.47^{\mathrm{a}}$ & $102.9^{\mathrm{a}}$ & $4.29^{\mathrm{b}}$ & 3.37 & 3.65 & $4.38^{\mathrm{b}}$ & 3.86 \\
\hline & & $91.08 \mathrm{c}$ & 99.61 & 99.92 & $106.21^{\mathrm{b}}$ & $99.2^{\mathrm{b}}$ & $4.57^{\mathrm{a}}$ & 3.40 & 3.68 & $5.04^{\mathrm{b}}$ & 4.04 \\
\hline & & 0.71 & 0.73 & 0.59 & 0.77 & 0.43 & 0.04 & 0.06 & 0.07 & 0.11 & 0.06 \\
\hline & & $*$ & NS & $*$ & $*$ & $*$ & $*$ & NS & NS & $*$ & NS \\
\hline \multicolumn{12}{|c|}{ Interaction CoQ10*Energy } \\
\hline \multirow{3}{*}{$\begin{array}{l}8 \\
\stackrel{2}{2} \\
\text { I }\end{array}$} & & 94.82 & $96.99^{\mathrm{abc}}$ & 96.22 & $101.73^{\mathrm{c}}$ & $97.44^{\mathrm{b}}$ & 4.15 & 3.41 & 3.72 & $4.62^{\mathrm{bc}}$ & 3.93 \\
\hline & $\operatorname{CoQ} 7.5_{\mathrm{s}}$ & 96.01 & $93.95^{\mathrm{c}}$ & 96.92 & $103.61^{\mathrm{c}}$ & $97.63^{b}$ & 4.10 & 3.4 & 3.86 & $4.74^{\mathrm{b}}$ & 3.98 \\
\hline & CoQ $7.5 n$ & 88.53 & $94.0^{\mathrm{c}}$ & 96.48 & $100.77^{\mathrm{c}}$ & $94.95^{\mathrm{b}}$ & 4.47 & 3.36 & 3.88 & $5.87 \mathrm{a}$ & 4.18 \\
\hline \multirow{3}{*}{ 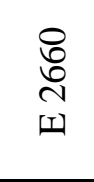 } & $\mathrm{C} 0 \mathrm{Q}(0)$ & 95.40 & $104.62^{\mathrm{a}}$ & 102.03 & $105.19^{c}$ & $101.81^{\mathrm{b}}$ & 4.65 & 3.52 & 3.60 & $4.14^{\mathrm{bc}}$ & 3.96 \\
\hline & CoQ $7.5_{s}$ & 99.69 & $108.18^{\mathrm{c}}$ & 109.75 & $115.33^{\mathrm{a}}$ & $108.2^{\mathrm{a}}$ & 4.48 & 3.33 & 3.44 & $4.03^{\mathrm{c}}$ & 3.74 \\
\hline & CoQ7.5 n & 93.62 & $105.2^{\mathrm{ab}}$ & 103.36 & $111.64^{\mathrm{ab}}$ & $103.46^{\mathrm{ab}}$ & 4.66 & 4.43 & 3.48 & $4.20^{\mathrm{bc}}$ & 3.91 \\
\hline \multicolumn{2}{|c|}{ \pm SE mean } & 1.0 & 0.73 & 0.83 & 1.10 & 0.61 & 0.06 & 0.08 & 0.10 & 0.15 & 0.09 \\
\hline \multicolumn{2}{|c|}{ Significant } & NS & * & $*$ & $*$ & $*$ & NS & NS & NS & $*$ & NS \\
\hline
\end{tabular}


Table (6): Egg quality of local Sinai hens fed diets containing different levels of Metabolizable energy and Coenzyme Q10

\begin{tabular}{|c|c|c|c|c|c|c|c|c|}
\hline & & & & & Variables & & & \\
\hline & actors & $\begin{array}{l}\text { Shape } \\
\text { index }\end{array}$ & $\begin{array}{l}\text { Shell } \\
\text { weight } \\
\%\end{array}$ & $\begin{array}{l}\text { Yolk } \\
\text { weight } \\
\%\end{array}$ & $\begin{array}{l}\text { Albumin } \\
\text { weight } \\
\%\end{array}$ & $\begin{array}{l}\text { Yolk } \\
\text { index }\end{array}$ & $\begin{array}{l}\text { Shell } \\
\text { thickness }\end{array}$ & $\begin{array}{l}\text { Haugh } \\
\text { u. }\end{array}$ \\
\hline Eners & $\mathrm{y} \mathrm{Kcal} / \mathrm{kg}$ & & & & & & & \\
\hline 2760 & & 0.777 & 12.07 & 29.72 & 58.21 & 0.218 & 0.311 & 91.22 \\
\hline 2660 & & 0.780 & 12.38 & 30.45 & 57.17 & 0.214 & 0.313 & 89.33 \\
\hline$\pm \mathrm{SE}$ & nean & 0.01 & 0.28 & 0.39 & 0.54 & 0.002 & 0.004 & 0.98 \\
\hline Signi & icant & NS & NS & $\mathrm{NS}$ & NS & NS & NS & NS \\
\hline Co Q & $10 \mathrm{mg} / \mathrm{Kg}$ & & & & & & & \\
\hline 0 & & 0.778 & 12.24 & 29.71 & 58.05 & 0.213 & $0.305^{\mathrm{b}}$ & 91.33 \\
\hline $7.5 \mathrm{~m}$ & $\mathrm{~g}(\mathrm{~s})$ & 0.782 & 12.54 & 30.56 & 56.89 & 0.213 & $0.322^{\mathrm{a}}$ & 89.50 \\
\hline $7.5 \mathrm{~m}$ & g (n) & 0.775 & 11.88 & 29.98 & 58.14 & 0.222 & $0.310^{\mathrm{ab}}$ & 90.00 \\
\hline$\pm \mathrm{SE}$ & nean & 0.007 & 0.34 & 0.47 & 0.66 & 0.003 & 0.005 & 1.21 \\
\hline Signi & icant & NS & NS & NS & NS & NS & $*$ & NS \\
\hline Intera & ction $\mathrm{CoQ}$ & Energy & & & & & & \\
\hline & C0Q (0) & 0.777 & 12.30 & 29.19 & 58.51 & 0.213 & $0.317^{\mathrm{c}}$ & 91.33 \\
\hline & $\begin{array}{l}\mathrm{CoQ} \\
\left(7.5_{\mathrm{s}}\right)\end{array}$ & 0.78 & 12.45 & 30.66 & 56.89 & 0.217 & $0.317^{\mathrm{c}}$ & 91.00 \\
\hline$\stackrel{8}{\stackrel{8}{2}}$ & $\begin{array}{l}\text { CoQ } \\
(7.5 \mathrm{n}) \\
\end{array}$ & 0.773 & 11.45 & 29.29 & 59.25 & 0.223 & $0.300^{\mathrm{d}}$ & 91.33 \\
\hline & C0Q (0) & 0.780 & 12.19 & 30.22 & 57.59 & 0.213 & $0.293^{\mathrm{e}}$ & 91.33 \\
\hline & $\begin{array}{l}\mathrm{CoQ} \\
\left(7.5_{\mathrm{s}}\right)\end{array}$ & 0.783 & 12.63 & 30.47 & 56.90 & 0.210 & $0.327^{\mathrm{a}}$ & 88.00 \\
\hline 융 & $\begin{array}{l}\text { CoQ } \\
\left(7.5_{n}\right) \\
\end{array}$ & 0.777 & 12.31 & 30.67 & 57.02 & 0.220 & $0.320^{\mathrm{b}}$ & 88.67 \\
\hline \pm SE & ean & 0.010 & 0.48 & 0.67 & 0.94 & 0.004 & 0.007 & 1.71 \\
\hline Signi & icant & NS & $\mathrm{NS}$ & NS & NS & NS & $*$ & NS \\
\hline
\end{tabular}

SE mean= standard error mean ; a,b,c :means in the same column bearing different superscripts are significantly different $(\mathrm{P} \leq 0.05)$. NS $=$ non-significant $; *=\mathrm{P} \leq 0.05$ 
Table (7): Blood hematology and viability (\%) of local Sinai laying hens fed diets containing different levels of Metabolizable energy and Coenzyme Q10

\begin{tabular}{|c|c|c|c|c|c|c|}
\hline \multirow{2}{*}{\multicolumn{2}{|c|}{$\begin{array}{c}\text { Traits } \\
\text { Factors }\end{array}$}} & \multirow{2}{*}{$\begin{array}{c}\text { WBC } \\
\left(\times 10^{3} / \mathbf{m m}^{3}\right)\end{array}$} & \multicolumn{2}{|c|}{ Count, \% } & \multirow{2}{*}{$\mathbf{H} / \mathbf{L}$} & \multirow{2}{*}{ Viability, \% } \\
\hline & & & $\mathbf{H}$ & $\mathbf{L}$ & & \\
\hline \multicolumn{7}{|c|}{ Energy $\mathrm{Kcal} / \mathrm{Kg}$ of diet } \\
\hline \multicolumn{2}{|c|}{ E1 2760} & $23 a$ & $21.11 \mathrm{~b}$ & 77.44 & $0.27 \mathrm{a}$ & 96.67 \\
\hline \multicolumn{2}{|c|}{ E2 2660} & $20 \mathrm{~b}$ & $23.67 \mathrm{a}$ & 75.00 & $0.32 b$ & 96.67 \\
\hline \multicolumn{2}{|c|}{ Pooled SEM } & 0.71 & 0.89 & 0.83 & 0.01 & 1.93 \\
\hline \multicolumn{2}{|c|}{ Significance } & $*$ & $*$ & NS & $*$ & NS \\
\hline \multicolumn{7}{|c|}{ C0 enzyme Q10 (Co Q10) (mg/kg) } \\
\hline \multicolumn{2}{|c|}{0.0} & 22 & $20.67 b$ & 78.17 & $0.27^{\mathrm{b}}$ & 96.67 \\
\hline \multicolumn{2}{|c|}{$7.5 \mathrm{~s}$} & 20 & $23.50 \mathrm{a}$ & 75.00 & $0.32^{\mathrm{a}}$ & 96.67 \\
\hline \multicolumn{2}{|c|}{$7.7 \mathrm{n}$} & 22.5 & $23 . .00 \mathrm{ab}$ & 75.00 & $0.31^{\mathrm{ab}}$ & 96.67 \\
\hline \multicolumn{2}{|c|}{ Pooled SEM } & 0.87 & 0.84 & 1.02 & 0.02 & 2.36 \\
\hline \multicolumn{2}{|c|}{ Significance } & NS & $*$ & NS & $*$ & NS \\
\hline \multicolumn{7}{|c|}{ Interaction Energy*Co Q10 } \\
\hline \multirow{3}{*}{$\frac{8}{2}$} & 0.0 & 24 & 19.33 & 79.33 & 0.24 & 96.67 \\
\hline & $\operatorname{CoQ}\left(7.5_{\mathrm{s}}\right)$ & 21 & 22.00 & 77.00 & 0.29 & 96.67 \\
\hline & $\operatorname{CoQ}\left(7.5_{\mathrm{n}}\right)$ & 24 & 22.00 & 76.00 & 0.29 & 96.67 \\
\hline \multirow{3}{*}{ 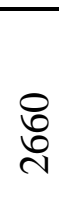 } & 0.0 & 20 & 22.00 & 77.00 & 0.29 & 96.67 \\
\hline & $\operatorname{CoQ}\left(7.5_{\mathrm{s}}\right)$ & 19 & 25.00 & 73.00 & 0.34 & 96.67 \\
\hline & $\operatorname{CoQ}\left(7.5_{\mathrm{n}}\right)$ & 21 & 24.00 & 75.00 & 0.32 & 96.67 \\
\hline \multicolumn{2}{|c|}{ Pooled SEM } & 1.23 & 1.19 & 1.44 & 0.02 & 3.33 \\
\hline \multicolumn{2}{|c|}{ Significance } & NS & NS & NS & NS & NS \\
\hline
\end{tabular}

$\mathrm{HB}=$ hemoglobin; $\mathrm{WBC}=$ white blood cells; $\mathrm{H}=$ heterophils cells; $\mathrm{L}=$ lymphocyte cells;

$\mathrm{SEM}=$ standard error mean ; $\mathrm{a}, \mathrm{b}$ :means in the same column bearing different superscripts are significantly different $(\mathrm{P} \leq 0.05)$. NS $=$ non-significant $; *=\mathrm{P} \leq 0.05$ 
Table( 8): Polyunsaturated fatty acids(\%) of eggs from local Sinai laying hens fed diets containing different levels of Metabolizable energy and Coenzyme Q10

\begin{tabular}{|c|c|c|c|c|}
\hline \multirow{2}{*}{\multicolumn{2}{|c|}{$\begin{array}{c}\text { Traits } \\
\text { Factors }\end{array}$}} & \multicolumn{3}{|c|}{ Polyunsaturated fatty acids (\%) } \\
\hline & & C18:2 $\omega 6$ & C18:2 $\omega 3$ & $\mathrm{C20:4 \omega 6}$ \\
\hline \multicolumn{5}{|c|}{ Energy $\mathrm{Kcal} / \mathrm{Kg}$ of diet } \\
\hline \multicolumn{2}{|l|}{ E1 2760} & $9.56^{\mathrm{b}}$ & 0.164 & $1.04^{\mathrm{b}}$ \\
\hline \multicolumn{2}{|l|}{ E2 2660} & $11.36^{\mathrm{a}}$ & 0.203 & $1.32^{\mathrm{a}}$ \\
\hline \multicolumn{2}{|c|}{ Pooled SEM } & 0.40 & 0.02 & 0.07 \\
\hline \multicolumn{2}{|c|}{ Significance } & $*$ & NS & $*$ \\
\hline \multicolumn{5}{|c|}{ C0 enzyme Q10 (mg/kg diet) } \\
\hline \multicolumn{2}{|l|}{0.0} & $8.64^{\mathrm{b}}$ & $0.127^{\mathrm{b}}$ & $1.19^{\mathrm{a}}$ \\
\hline \multicolumn{2}{|c|}{7.5 syncretic $\left(7.5_{s}\right)$} & $8.56^{\mathrm{b}}$ & $0.066^{\mathrm{b}}$ & $0.97^{\mathrm{b}}$ \\
\hline \multicolumn{2}{|c|}{7.7 natural $\left(7.5_{\mathrm{n}}\right)$} & $14.18^{\mathrm{a}}$ & $0.357^{\mathrm{a}}$ & $1.38^{\mathrm{a}}$ \\
\hline \multicolumn{2}{|c|}{ Pooled SEM } & 0.49 & 0.03 & 0.09 \\
\hline \multicolumn{2}{|c|}{ Significance } & $*$ & & $*$ \\
\hline \multicolumn{5}{|c|}{ Interaction Energy*Co Q10 } \\
\hline \multirow{3}{*}{$\stackrel{8}{\stackrel{8}{2}}$} & 0.0 & 7.28 & 0.110 & 0.89 \\
\hline & $\operatorname{CoQ}(7 . s)$ & 7.65 & 0.037 & 0.81 \\
\hline & $\operatorname{CoQ}(7 \cdot n)$ & 13.75 & 0.345 & 1.41 \\
\hline \multirow{3}{*}{ 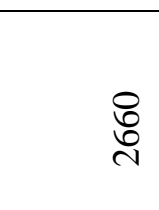 } & 0.0 & 10.00 & 0.145 & 1.48 \\
\hline & $\operatorname{CoQ}\left(7.5_{\mathrm{s}}\right)$ & 9.00 & 0.095 & 1.13 \\
\hline & $\operatorname{CoQ}\left(7.5_{n}\right)$ & 9.46 & 0.370 & 1.36 \\
\hline \multicolumn{2}{|c|}{ Pooled SEM } & 14.62 & 0.04 & 0.11 \\
\hline \multicolumn{2}{|c|}{ Significance } & NS & NS & NS \\
\hline
\end{tabular}

C18:2 $\omega$ 6= Linolnic acid ; C18:2 $\omega$ 3=Lenolenic acid ; C20:4 $\omega 6=$ Arachidonic acid

$\mathrm{SEM}=$ standard error mean ; $\mathrm{a}, \mathrm{b}$ :means in the same column bearing different superscripts are significantly different $(\mathrm{P} \leq 0.05)$. NS $=$ non-significant; $*=\mathrm{P} \leq 0.05$ 
Table( 9): Saturated and monounsaturated fatty acids (\%) of eggs from local Sinai laying hens fed diet containing different levels of Metabolizable energy and Coenzyme Q10

C14:0=Myristic acid ; C16:0=Pametic acid ; C18:0=Stearic acid C18:1 $\omega 9=$ Oleic acid C18:1 $\omega 7=$ Vaccinic acid; C16:1 $\omega 9=$ Palmitoleic acid; SEM= standard error mean ; a,b,c,d,e :means in the same column bearing different superscripts are significantly different $(\mathrm{P} \leq 0.05)$; NS = nonsignificant; $*=\mathrm{P} \leq 0.05$ 
Table (10): Nutrients digestibility coefficient of local Sinai laying hens fed diets containing different levels of Metabolizable energy and Coenzyme Q10

\begin{tabular}{|c|c|c|c|c|c|c|c|c|c|}
\hline \multirow{2}{*}{\multicolumn{2}{|c|}{$\begin{array}{c}\text { Traits } \\
\text { Factors }\end{array}$}} & \multicolumn{8}{|c|}{ Nutrients digestibility coefficient } \\
\hline & & DM & $\mathbf{C P}$ & $\mathbf{E E}$ & $\mathbf{C F}$ & $\begin{array}{l}\text { Ash } \\
\text { R. }\end{array}$ & OM & NFE & TDN \\
\hline \multicolumn{10}{|c|}{ Energy $\mathrm{Kcal} / \mathrm{Kg}$ of diet } \\
\hline \multicolumn{2}{|c|}{ E1 2760} & 71.14 & 95.29 & $42.89^{\mathrm{a}}$ & 19.95 & 48.31 & 74.18 & 78.83 & 61.68 \\
\hline \multicolumn{2}{|c|}{ E2 2660} & 70.46 & 94.75 & $36.91^{\mathrm{b}}$ & 24.01 & 54.85 & 72.71 & 78.66 & 60.45 \\
\hline \multicolumn{2}{|c|}{ Pooled SEM } & 0.64 & 0.50 & 1.87 & 1.57 & 1.43 & 058 & 0.81 & 0.57 \\
\hline \multicolumn{2}{|c|}{ Significance } & NS & NS & $*$ & NS & NS & NS & NS & NS \\
\hline \multicolumn{10}{|c|}{ C0 enzyme Q10 (Co Q10) (mg/kg) } \\
\hline \multicolumn{2}{|l|}{0.0} & 70.52 & 94.96 & $27.57^{b}$ & 21.03 & 49.62 & 73.34 & $79.64^{\mathrm{a}}$ & 60.47 \\
\hline \multicolumn{2}{|l|}{$7.5 \mathrm{~s}$} & 71.63 & 94.83 & $28.42^{\mathrm{b}}$ & 19.93 & 49.62 & 74.41 & $80.67^{\mathrm{a}}$ & 61.06 \\
\hline \multicolumn{2}{|l|}{$7.7 \mathrm{n}$} & 70.26 & 95.27 & $63.71^{\mathrm{a}}$ & 24.97 & 54.34 & 72.59 & $75.93^{\mathrm{b}}$ & 61.67 \\
\hline \multicolumn{2}{|c|}{ Pooled SEM } & 0.78 & 0.61 & 2.29 & 1.92 & 1.75 & 0.71 & 0.99 & 0.70 \\
\hline \multicolumn{2}{|c|}{ Significance } & NS & NS & $*$ & NS & NS & NS & $*$ & NS \\
\hline \multicolumn{10}{|c|}{ Interaction Energy*Co Q10 } \\
\hline \multirow{3}{*}{$\frac{8}{2}$} & 0.0 & 70.67 & 95.37 & $31.77_{\mathrm{b}}$ & 17.54 & 45.38 & 73.96 & $80.58^{\mathrm{ab}}$ & 61.56 \\
\hline & $7.5 \mathrm{~s}$ & 73.33 & 95.52 & $32.52^{\mathrm{b}}$ & 18.64 & 49.33 & 76.33 & $82.75^{\mathrm{a}}$ & 62.77 \\
\hline & $7.5 \mathrm{n}$ & 69.42 & 94.97 & $64.38^{\mathrm{a}}$ & 23.67 & 50.21 & 72.24 & $73.32^{\mathrm{c}}$ & 60.70 \\
\hline \multirow{3}{*}{$\begin{array}{l}\stackrel{8}{0} \\
\stackrel{2}{1}\end{array}$} & 0.0 & 70.36 & 94.54 & $23.37^{\mathrm{b}}$ & 24.52 & 53.87 & 72.71 & $78.70^{\mathrm{ab}}$ & 59.37 \\
\hline & $7.5 \mathrm{~s}$ & 69.92 & 94.14 & $24.33^{\mathrm{b}}$ & 21.22 & 52.21 & 72.48 & $78.77^{\mathrm{ab}}$ & 59.35 \\
\hline & $7.5 \mathrm{n}$ & 71.10 & 95.57 & $63.03^{\mathrm{a}}$ & 26.28 & 58.46 & 72.94 & $78.53^{a b c}$ & 62.64 \\
\hline \multicolumn{2}{|c|}{ Pooled SEM } & 1.10 & 0.86 & 3.24 & 2.71 & 2.48 & 1.01 & 1.39 & 0.99 \\
\hline \multicolumn{2}{|c|}{ Significance } & NS & NS & $*$ & NS & NS & NS & $*$ & NS \\
\hline
\end{tabular}

SEM= standard error mean ; $a, b$ :means in the same column bearing different superscripts are significantly different $(\mathrm{P} \leq 0.05)$. NS $=$ non-significant; $*=\mathrm{P} \leq 0.05$ 
Table (11): Economic efficiency of egg production from local Sinai laying hens fed diets containing different levels of Metabolizable energy and Coenzyme Q10

\begin{tabular}{|c|c|c|c|c|c|c|c|c|}
\hline & ros & $\begin{array}{l}\text { Total feed } \\
\text { consumed/ } \\
\text { hen }(\mathrm{Kg})\end{array}$ & $\begin{array}{c}\text { Total } \\
\text { feed } \\
\text { consumed } \\
\text { cost/ hen } \\
(\mathrm{LE})^{1}\end{array}$ & $\begin{array}{c}\text { Egg } \\
\text { number/ } \\
\text { hen }\end{array}$ & $\begin{array}{c}\text { Price } \\
\text { of one } \\
\text { egg } \\
\text { (LE) }\end{array}$ & $\begin{array}{l}\text { Total } \\
\text { return } \\
(\mathrm{LE})\end{array}$ & $\begin{array}{l}\text { Net } \\
\text { return } \\
(\mathrm{LE})\end{array}$ & $\begin{array}{l}\text { EEF } \\
(\%)^{2}\end{array}$ \\
\hline Energy & $\overline{\mathrm{cal} / \mathrm{Kg}}$ & diet & & & & & & \\
\hline & & 10.73 & 31.99 & 62.48 & 0.70 & 43.72 & 11.73 & $36.88^{\mathrm{b}}$ \\
\hline E2 266 & & 11.6 & 34.21 & 68.47 & 0.70 & 47.93 & 13.72 & $40.13^{\mathrm{a}}$ \\
\hline Pooled & & & & & & & & 0.92 \\
\hline Signific & & & & & & & & * \\
\hline C0 enz & Q10 & o Q10) (mg/l & & & & & & \\
\hline 0.0 & & 10.06 & 32.15 & 64.11 & 0.70 & 44.88 & 12.74 & $39.62^{\mathrm{b}}$ \\
\hline $7.5 \mathrm{~s}$ & & 11.42 & 33.22 & 68.74 & 0.70 & 48.12 & 14.91 & $44.93^{\mathrm{a}}$ \\
\hline $7.7 \mathrm{n}$ & & 11.01 & 33.93 & 63.56 & 0.70 & 44.47 & 10.53 & $30.96^{c}$ \\
\hline Pooled & & & & & & & & 1.12 \\
\hline Signific & & & & & & & & $*$ \\
\hline Interac & on Ener & $*$ Co Q10 & & & & & & \\
\hline & 0.0 & 1082 & 31.63 & 6306 & 0.70 & 44.14 & 12.51 & $39.57^{\mathrm{ab}}$ \\
\hline 8 & $7.5 \mathrm{~s}$ & 10.84 & 31.72 & 64.94 & 0.70 & 45.46 & 13.74 & $43.55^{\mathrm{a}}$ \\
\hline & $7.5 \mathrm{n}$ & 10.54 & 32.61 & 59.44 & 0.70 & 41.55 & 8.94 & $27.52^{\mathrm{c}}$ \\
\hline & 0.0 & 11.30 & 32.66 & 65.17 & 0.70 & 45.62 & 12.96 & $39.67^{\mathrm{ab}}$ \\
\hline 8 & $7.5 \mathrm{~s}$ & 12.01 & 34.72 & 72.55 & 0.70 & 50.79 & 16.07 & $46.31^{\mathrm{a}}$ \\
\hline & $7.5 n$ & & 35.25 & & 0.70 & 47.38 & 12.13 & $34.41^{\mathrm{bc}}$ \\
\hline Pooled & $\overline{E M}$ & & & & & & & 1.59 \\
\hline Signific & & & & & & & & $*$ \\
\hline
\end{tabular}

LE= Egyptian pound. ${ }^{1}$ According to price at the experimental time $\operatorname{EEF}(\%)=$ economic efficiency $(\%)=($ Net return LE $/$ Total feed cost LE $) \times 100^{2}$ $a, b, c, .$. : means in the same column bearing different superscripts are significantly different $(\mathrm{p} \leq$ $0.05)$ 


\section{REFERENCES}

Abou- Raya, A.K. and A.G.H. Galal (1971). Evaluation of poultry feeds in digestion traits with reference to some factors involved. A.R.E.J Anim. Prod., 11: 207-221.

American Heart Association (1996). Eggs: AHA scientific/medical position. Heart and Stroke A-Z Guide. American Heart Association, Dallas, TX.

Andre'e, P., G. Dallner and L. Ernster (1998). Ubiquinol: An endogenous lipid-soluble antioxidant in animal tissues. Pages 293 - 314 in Free Radicals, Oxidative Stress, and Antioxidants. T. $\mathrm{O}^{\prime}$ zben, ed., Plenum Press, New York.

Association of Official Analytical Chemists (AOAC) (1995). Official methods of analysis. $15^{\text {th }}$ Ed. Published by the AOAC., Washington, D.C., USA.

Balnave, D. and D. Robinson (2000). Energy requirements of imported Brown layer strains. A report for the rural industries research and development corporation. RIRDC Publication No 00/179

Bentinger, M.; K. Brismar and G. Dallner (2007). The antioxidant role of coenzyme Q. Mitochondrion. 7:S41-S50.

Bhagavan, H.N. and R.K. Chopra (2006). Coenzyme Q10 : absorption, tissue uptake, metabolism and pharmacokinetics. Free Rad-ical Research,40: 445-453

Brandt, U (1999). Proton translocation in the respiratory chain involving ubiquinone - a hypothetical semiquinone switch mechanism for complex I. Biofactors 9:95-102.

British Nutrition Foundation (1992). Unsaturated Fatty Acids Nutritional and Physiological Significance. The Report of the British Nutrition
Foundation's Task Force. Chapman and Hall, London, UK.

Cabrini, L.; V. Barzanti; M. Cipollone; M.,D. Fiorentini; G. Grossi; B. Tolomelli; L. Zambonin and $\mathrm{L}$. Landi (2001). Antioxidants and total peroxyl radical-trapping ability of olive and seed oils. J. Agric. Food Chem. 49:6026-6032.

Campbell, T.W. (1995). Avian Hematology and Cytology, Iowa State University Press, Ames, Iowa, USA. pp: 3-19.

Challem, J. (2005). Nutrients that enhance energy and prevent DNA damage. In: Feed Your Genes Right. pp. 41-53. John Wiley \& Sons, Hoboken, New Jersey.

Cherian,G. and J. S. Sim (1991). Effect of feeding full fat flax and canola seeds to laying hens on the fatty acid composition of eggs, embryos and newly hatched chicks. Poult. Sci. 70:917-922.

Ciftci, I.; E. Yenice; D. Gokceyrek and E. Ozturk (2003). Effects of energy level and enzyme supplementation in wheat-based layer diets on hen performance and egg quality. Acta Agric. Scand. Sect. A Anim. Sci. 53:113-119.

Crane, F. L. (2001). Biochemical functions of coenzyme Q10. J. Am. Coll. Nutr. 20:591-598.

Crane, F. L. (2007). Discovery of ubiquinone (coenzyme Q) and an overview of function. Mitochondrion. 7:S2-S7.

Duncan, D.B. (1955). Multiple ranges and multiple f-test, Biometries 11: 1-42.

Fathi, M. (2015). Effects of Coenzyme Q10 supplementation on growth Performance, some hematological parameters, plasma enzymes activities in broilers with pulmonary hypertension syndrome (PHS). 
Iranian Journal of Applied Animal Science 5(1), 147-153.

Feed Composition Tables for Animals and Poultry Feedstuffs Used in Egypt (2001). Technical Bulletin No.,1, Central Lab. For Food and Feeds(CLFF) Ministry of Agric. Res. Cent. Egypt.

Ernster, L. and . Dallner (1995). Biochemical, physiological and medical aspects of ubiquinone function. Biochim Biophys Acta 1271: 195-204.

Geng,A.L.; Y. M. Guo and Y. Yang (2004). Reduction of ascites mortality in broilers by Coenzyme Q10. Poultry Science 83:1587-1593.

Geng, A.L. and Y. M. Guo (2005). Effects of dietary coenzyme Q10 supplementation on hepatic mitochondrial function and the activities of respiratory chain-related enzymes in ascitic broiler chickens. Br. Poultry Science 46(5): 626-634.

Gross, W.B. and P.B. Siegel (1986). Effects of initial and second periods of fasting on heterophil/lymphocyte ratios and body weight. Av. Dis., 30:345 346.

Gunawardana, P.; D.A.Roland and M.M. Bryant (2008). Effect of energy and protein on performance, egg Components, egg solids, egg Quality, and profits in molted hyLine W-36 Hens. J. Appl. Poult. Res. 17, 432-439.

Gunawardana, P.; D. A. Roland, Sr. and M. M. Bryant (2009). Effect of dietary energy, protein, and a versatile enzyme on hen performance, egg solids, egg composition, and egg quality of Hy-Line W-36 hens during second cycle, phase two. J. Appl. Poult. Res. 18:43-53.

Haas, R. Ed. (2007). The role of coenzyme $\mathrm{Q}$ in cellular metabolism : Current biological and clinical aspects. Mitochondrion, 7 (Suppl. 1): S1S180.
Harms, R.H.; M.A. Motl and G.B. Russell (2000). Influence of age at lighting dietary calcium and addition of corn oil on early egg weight from commercial layers. Journal of Applied Poultry Research, 9: 334- 342.

Hasegawa, S.; Honda, K.; $\mathbf{H}$. Kamisoyama, and K. Hayashi (2009). Effect of functional feed ingredients on the quantity and quality of chicken meat and egg. World Poultry Science Association, Proceedings of the $19^{\text {th }}$ European Symposium on Quality of poultry Meat, $13^{\text {th }}$ European Symposium on the Quality of Egg and Egg Products, Turku, Finland, 21-25 June 2009.

Honda, K.; T. Saneyasu; T. Motoki; Y. Park and H. Kamisoyama (2013). Dietary Coenzyme Q10 suppressed hepatic hydroxymethylglutaryl-CoA reductase activity in latying hens. Biosci. Biotechnol. Biochem. 77(7):1-3.

Hussein M.A.A.; M.E. Kout El-Kloub ; M.K. Gad El-Haq and Abbas AM. (2010). Optimum metabolizable energy and crude protein levels for Sinai laying hens. Egypt poultry Sci. Vol(30)(IV):1073-1095.

Jakobsen , P.E.; S. G. Kirston and H. Nielsen (1960). Digestibility trails with poultry. 322 bretning fra foprsgs labratriet udgivest statens .Husdybug sudvalg kobenhann.

Jiménez-Moreno, E.; J.M. GonzalezAlvaradol; A. De Coca-Sinova; R. Lazaro and G.G. Mateos (2009). Effects of source of fiber on the development and $\mathrm{pH}$ of the gastrointestinal tract of broilers. Animal Feed Science Technol., 54: 93-101.

Kalen, A.; B. Norling ; E.L. Appelkvist and Dallner G (1987): Ubiquinone biosynthesis by the microsomal fraction of rat liver. Biochim Biophys Acta 926:70-78. 
Kalen, A.; E. L. Appelkvist and G. Dallner (1989). Age-related changes in the lipid compositions of rat and human tissues. Lipids. 24:579-584.

Kamisoyama, H.; k. Honda; k. Kitaguchi and s. Hasegawa (2010). Transfer of dietary coenzyme Q10 into the egg yolk of laying hens. Journal of Poultry Science. 47:28-33.

Katan, M.; P. Zock and R. Mensink. (1995). Dietary oils, serum lipoproteins, and coronary heart disease. Am. J. Clin. Nutr. 61(Suppl.):1368-1373.

Kikusato, M.; K. Nakamura; Y. Mikami; A. Mujahid and M. Toyomizu(2015). The suppressive effect of dietary coenzyme Q10 on mitochondrial reactive oxygen species production and oxidative stress in chickens exposed to heat stress. Animal Science Journal doi: 10.1111/asj.12543

Mathlouthi, N.; M. Larbier; M. A. Mohamed and M. Lessire (2002). Performance of laying hens fed wheat, wheat-barley or wheat-barleywheat bran based diets supplemented with xylanase. Can. J. Anim. Sci. 82:193-199.

Meluzzi, A.; F. Sirri, G. Manfreda; N. Tallarico, and A. Franchini (2000). Effects of dietary vitamin $\mathrm{E}$ on the quality of table eggs enriched with n3 long-chain fatty Acids. Poultry Science 79:539-545.

Meluzzi, A.; F. Sirri; N. Tallarico and A. Franchini (2001). Effect of different vegetable lipid sources on the fatty acid composition of egg yolk on hen performance. Arch. Geflu" gelkd. 65:207-213.

Mohiti-Asli, M.; M. Shivazad; M. Zaghari;M. Rezalan; S. Aminzadeh and G.G. Mateos ( 2012). Effects of feeding regimen, fiber inclusion, and crude protein content of the diet on performance and egg quality and hatchability of eggs of broiler breeder hens. Poult. Sci. 91, 3097-3106.

Peguri, A. and C. Coon. (1991). Effect of temperature and dietary energy on layer performance. Poult. Sci. 70:126-138.

Pregnolato, P., Maranesi, M., Mordenti, T., Turchetto, E., Barzanti, V. and Grossi, G. (1994). Coenzyme Q10 and Q9 content in some edible oils. Riv. Ital. Sostanze Grasse. 71:503505.

Quinn, P.J.; J.P. Fabisiak and V.E. Kagan (1999). Expansion of the antioxidant function of vitamin $\mathrm{E}$ by coenzyme Q. Biofactors 9:149-154.

Ritchie, B. W.; J. G. Harrison, and R. L. Harrison (1994). Avian Medicine. Winger's Publishing Inc, Florida, USA, pp. 176-198.

Simopoulos, A. P. and J. Robinson (1998). The Omega Plan, Harper Collins Publishers, New York.

SPSS. (2008). SPSS User's Guide Statistics. Ver. 17. Copyright SPSS Inc., USA.

Takahashi, T.; T. Okamoto; K. Mori; H. Sayo and T. Kishi (1993). Distribution of ubiquinone and ubiquinol homologues in rat tissues and subcellular fraction. Lipids 28:803-809.

Tercic, D.; Barbara Kotnik, B.; Gregor Gorjanc, G.; Jazbec K.P. and Antonija Holcman, A. (2011). The effect of Coenzyme Q10 and lipoic acid added to the feed of hens on physical characteristics of eggs Vol. 76 No. 3 (209-211).

Turunen, M.; P. Sindelar and G. Dallner (1999). Induction of endogenous coenzyme Q biosynthesis by administration of peroxisomal inducers. Biofactors 9:131-140.

Williams, K. C. (1992). Some factors aff ecting albumen quality with particular reference to Haugh unit score. World Poultry Sci J 48: 5-16. 
Wu, M., M. Brynt.; R.A. Voilet and D.A. Roland (2005). Effect of dietary energy on performance and egg composition of bovans white and dekalb whit hens during phase I. Poultry Science Journal, 84: 16101615.
Yu, C.A.; K-P. Zhang; H. Deng; D. Xia H. Klm; J. Deisenhofer, and L.Yu (1999). Structure and reaction mechanisms of the multifunctional mitochondrial cytochrome bc1 complex. Biofactors 9:103-110.

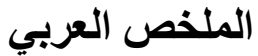 \\ تـاثير إضافة الإنزيم المساعد كيو · 1 الصناعي أو الطبيعي من زيت الصوي الصويا علي الأداء الإنتاجي

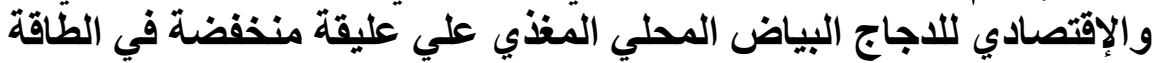

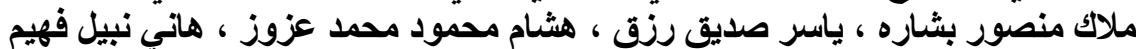

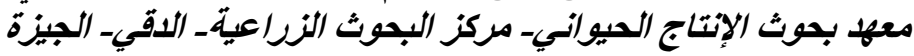

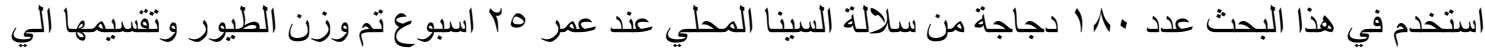

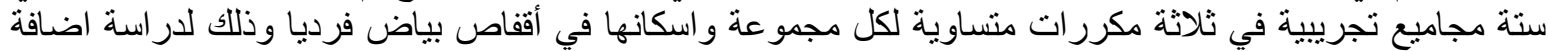

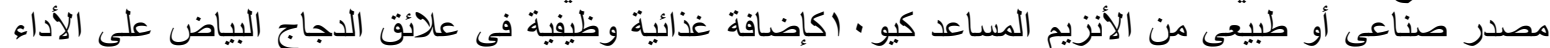

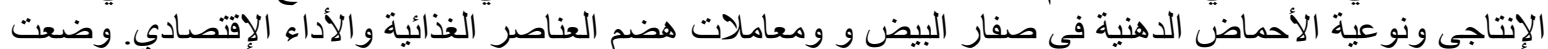

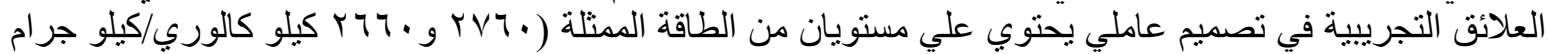

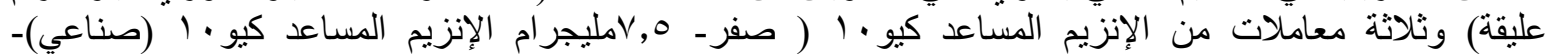

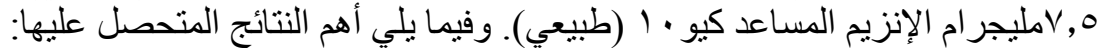

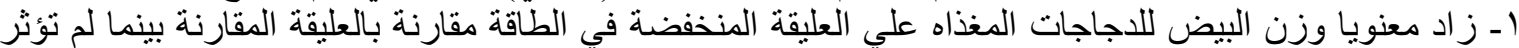

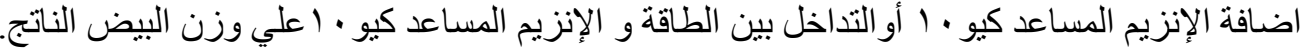

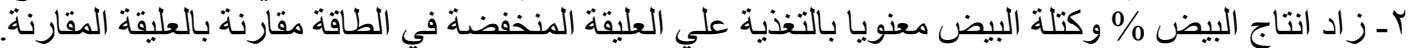

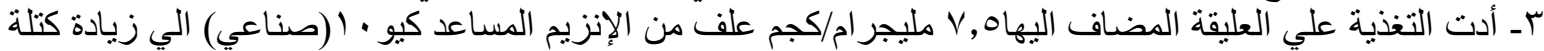

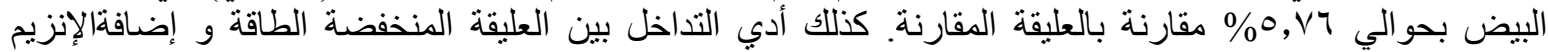

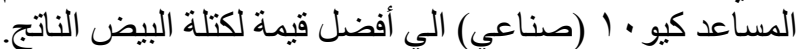

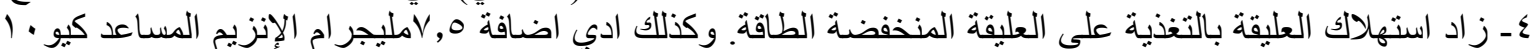

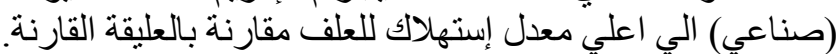

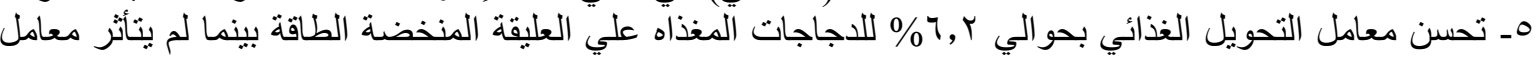

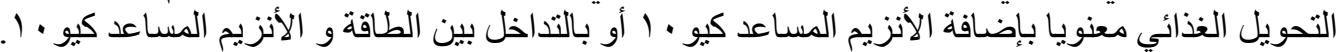

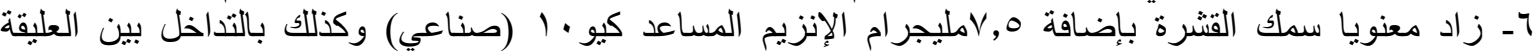

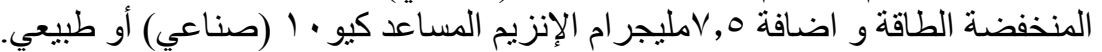

بالتغذية علي العليقة H/ Lymphocyte (L) و النسبة بين خلايا V(H) Heterophil المنخفضة في الطاقة مقارنة بالعليقة المقارنة.

بالتغذية علي العليقة المضاف اليها

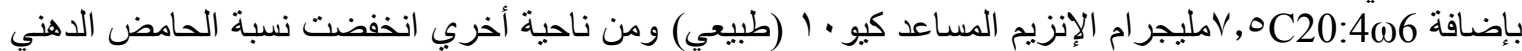

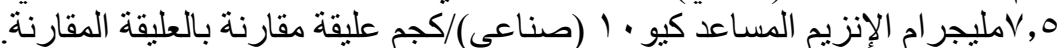

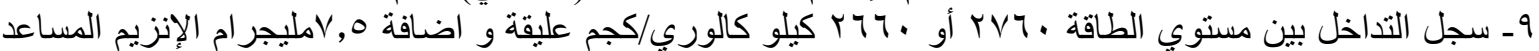
مقارنة بالعليقة المقارنة النقل

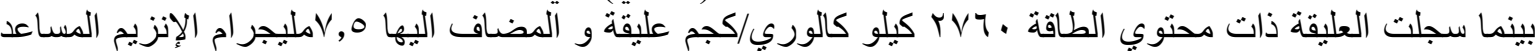

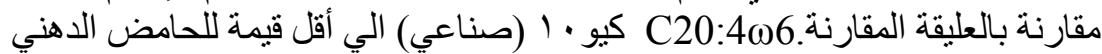

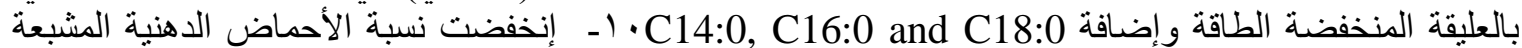

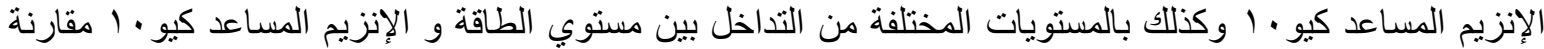
بالعليقة المقارنة.

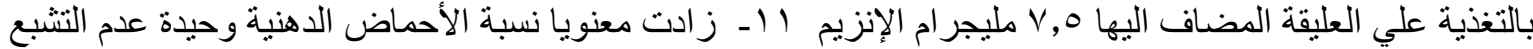

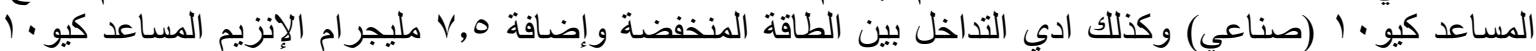

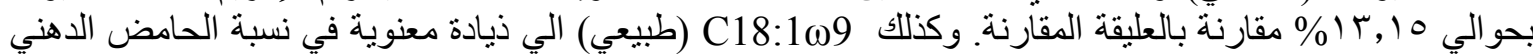


انخفضت نسبة الأحماض الدهنية المشبعة الي العديدة عدم التشبع بالعليقة المنخفضة الطاقة والإنزيم المساعد كيو • طبيعي و التداخل بين الطاقة المنخفضة والإنة الإنزيم المساعد كيو · ا طبيعي او صناعي مقارنة العليقة المقارنة.

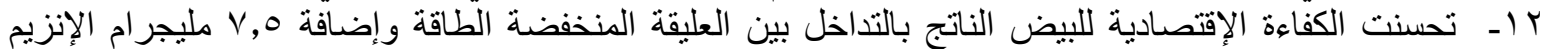

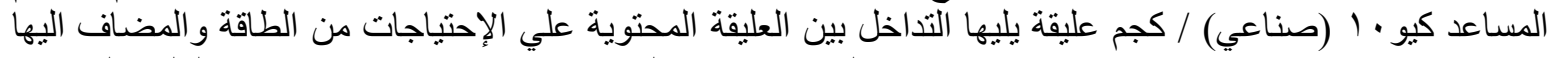

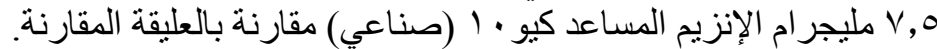

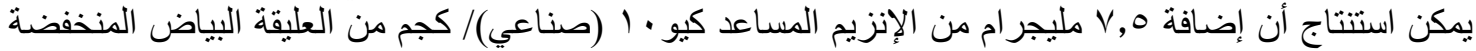

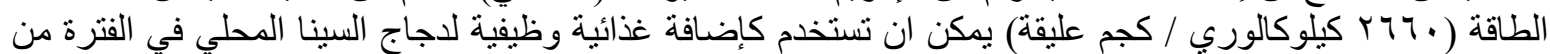

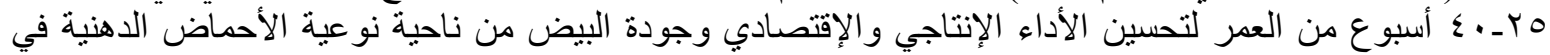
صفار البيض. 